\title{
Energy Use of Set-Top Boxes and Telephony Products in the U.S.
}

\author{
Karen B. Rosen, Alan K. Meier, and Stephan Zandelin \\ Environmental Energy Technologies Division \\ Lawrence Berkeley National Laboratory \\ University of California \\ Berkeley, California 94720
}

June 2001

This report is available online at: http://eetd.lbl.gov/ea/reports/45305/

This work was supported by the Assistant Secretary for Energy Efficiency and Renewable Energy of the U.S. Department of Energy under Contract No. DE-AC03-76SF00098 


\section{LBNL-45305}

\section{DISCLAIMER}

This document was prepared as an account of work sponsored by the United States Government. While this document is believed to contain correct information, neither the United States Government nor any agency thereof, nor the Regents of the University of California, nor any of their employees, makes any warranty, express or implied, or assumes any legal responsibility for the accuracy, completeness, or usefulness of any information, apparatus, product, or process disclosed, or represents that its use would not infringe privately owned rights. Reference herein to any specific commercial product, process, or service by its trade name, trademark, manufacturer, or otherwise, does not necessarily constitute or imply its endorsement, recommendation, or favoring by the United States Government or any agency thereof, or The Regents of the University of California. The views and opinions of authors expressed herein do not necessarily state or reflect those of the United States Government or any agency thereof or The Regents of the University of California. 


\section{EXECUTIVE SUMMARY}

The goal of this investigation was to estimate the 1999 energy consumption of set-top boxes and telephony products in the U.S. residential sector. These two products belong to the electricity end-use category labeled "miscellaneous" or "other" by the U.S. Department of Energy's Energy Information Agency (EIA). Results of this study will be used to identify new energy conservation opportunities and to align programs with those opportunities.

We conducted a bottom-up analysis for set-top boxes and telephony products using our own power measurements and stock and usage estimates from secondary sources.

The most common set-top boxes in U.S. homes in 1999 were analog cable boxes, digital cable boxes, wireless receivers, and game consoles. Figure ES-1 shows the range and mean value of the set-top power measurements we collected for this study.

Figure ES-1. Set-top Power Measurements

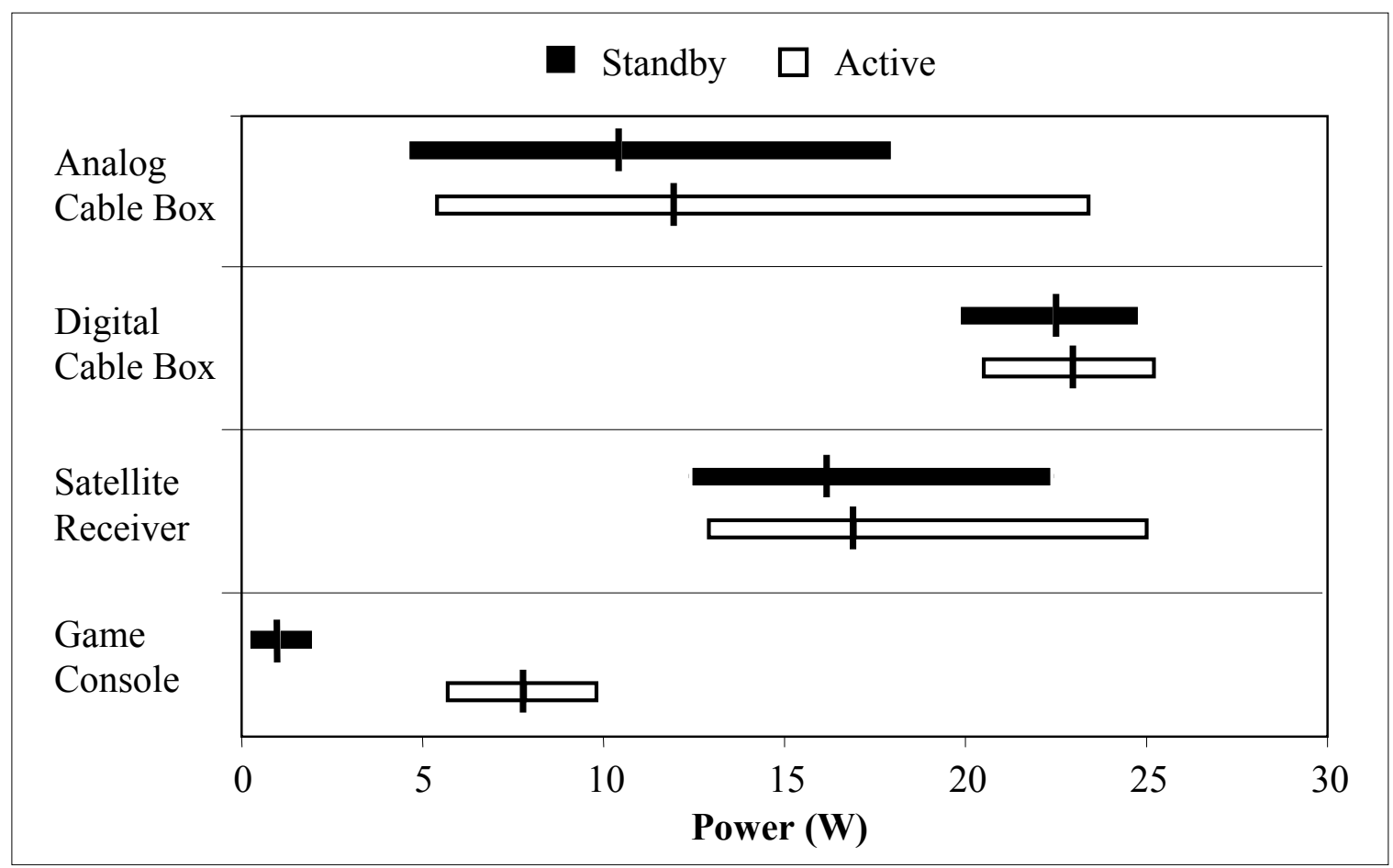

According to these measurements, analog cable boxes and wireless receivers draw between 10 and 15 watts, while digital cable boxes draw between 20 and 25 watts in both the Active and Standby modes. Video games used less than 2 watts in Standby mode, and about 8 watts when Active. Based on these figures, typical usage patterns, and stock 
estimates, we estimate that set-top boxes accounted for $0.7 \%$ of residential electricity use in 1999. Energy consumption estimates for set-top boxes are summarized in Table ES-1.

Table ES-1. National Energy Consumption of Set-top Boxes

\begin{tabular}{|lcccc|}
\hline Type of Set-top & $\begin{array}{c}\text { UEC } \\
(\mathbf{k W h} / \mathbf{y r})\end{array}$ & $\begin{array}{c}\text { Number of } \\
\text { Units (millions) }\end{array}$ & $\begin{array}{c}\text { U.S. Energy } \\
\text { Consumption } \\
\text { (TWh/yr) }\end{array}$ & $\begin{array}{c}\text { Share of U.S. } \\
\text { Residential } \\
\text { Electricity } \\
\text { Consumption }\end{array}$ \\
\hline Cable, Analog & 95 & 45 & 4.3 & $0.37 \%$ \\
\hline Cable, Digital & 200 & 3.8 & 0.7 & $0.07 \%$ \\
\hline Wireless & 140 & 13 & 1.9 & $0.16 \%$ \\
\hline Game Console & 10 & 54 & 0.5 & $0.05 \%$ \\
\hline Total & & $\mathbf{1 1 6}$ & $\mathbf{7 . 4}$ & $\mathbf{0 . 6 5 \%}$ \\
\hline
\end{tabular}

Our investigation of telephony products included answering machines, cordless phones, cordless phone answering machine combination units, and mobile phone chargers. Figure ES-2 shows the ranges and mean values of the telephony power measurements we collected for this study.

Figure ES-2. Telephony Power Measurements

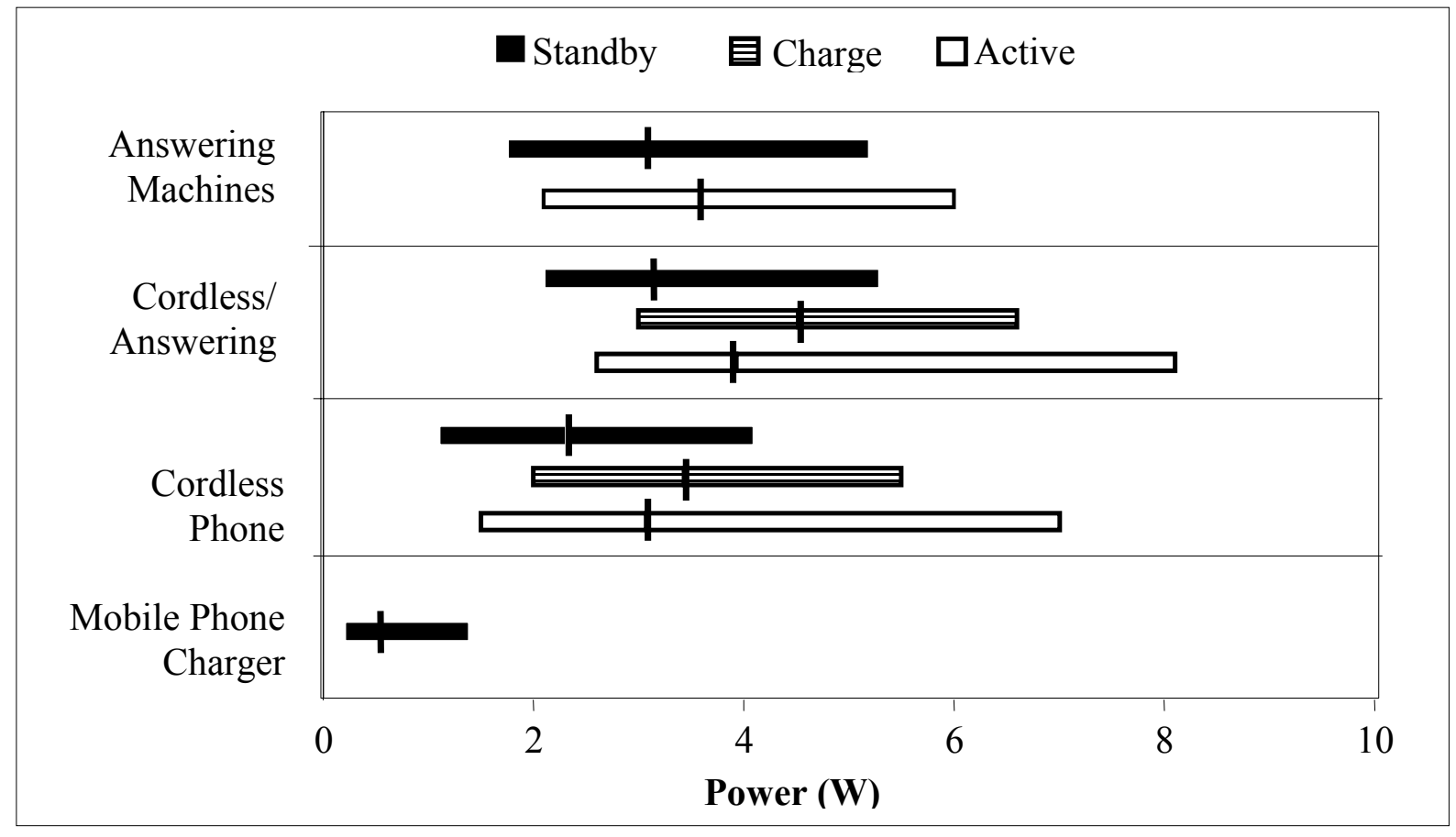


According to these measurements, answering machines, cordless phones, and combination units use between 2 and 3 watts in both the Active and Standby modes. Mobile phone chargers use about 1 watt in standby. We did not collect power measurements for battery charging because energy used during this mode is more easily estimated from battery capacity.

Based on these measurements, typical usage patterns, and U.S. stock, we estimate that these telephony products account for $0.5 \%$ of U.S. residential electricity consumption. Unit (UEC) and national energy consumption values for telephony products are summarized in Table ES-2.

Table ES-2. Energy Consumption of Residential Telephony

\begin{tabular}{|lcccc|}
\hline Telephony Product & $\begin{array}{c}\text { UEC } \\
(\mathbf{k W h} / \mathbf{y r})\end{array}$ & $\begin{array}{c}\text { Number } \\
\text { of Units } \\
\text { (millions) }\end{array}$ & $\begin{array}{c}\text { U.S. Energy } \\
\text { Consumption } \\
\text { (TWh/yr) }\end{array}$ & $\begin{array}{c}\text { Share of U.S. } \\
\text { Residential } \\
\text { Electricity } \\
\text { Consumption }\end{array}$ \\
\hline Answering Machines & 26 & 77 & 2.0 & $0.17 \%$ \\
\hline Cordless Phones & 28 & 87 & 2.4 & $0.21 \%$ \\
\hline Cordless/Answering & 36 & 35 & 1.3 & $0.11 \%$ \\
\hline Mobile Chargers & 9 & 52 & 0.3 & $0.03 \%$ \\
\hline Total U.S. & & $\mathbf{2 5 1}$ & $\mathbf{6 . 0}$ & $\mathbf{0 . 5 2 \%}$ \\
\hline
\end{tabular}

Together, set-tops and telephony constituted $1.2 \%$ of U.S. residential electricity consumption in 1999. Standby power use accounted for about $60 \%$ of this energy use.

The combined total energy use of the products investigated for this study and those researched previously for this series of reports account for about $6.6 \%$ of residential electricity use in the U.S., as shown in Figure ES-3. 
Figure ES-3. 1999 Residential Electricity Consumption [1][2][3]

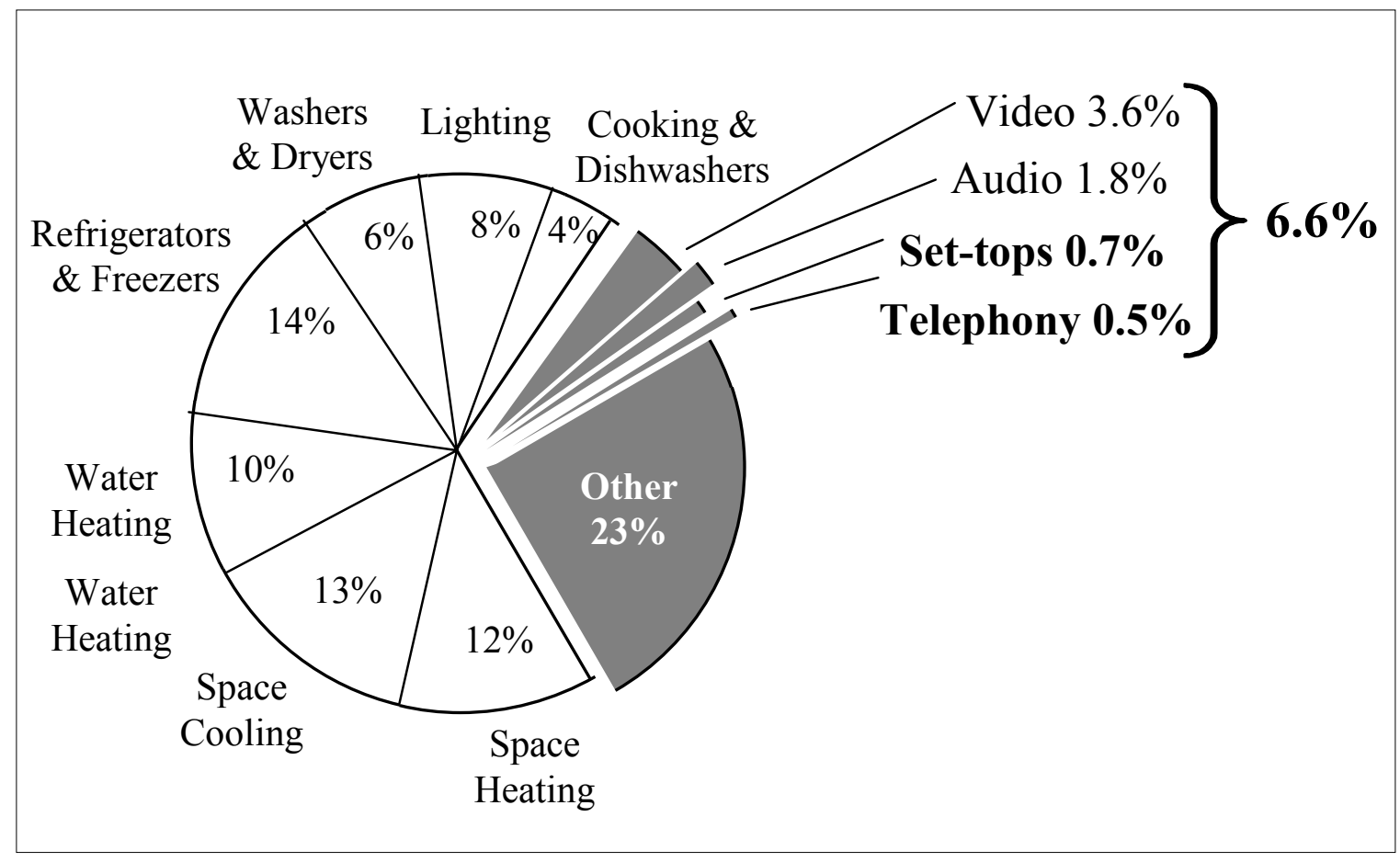

Over the next 10 years, the energy use of set-top boxes will grow as high-power digital set-top boxes gain in popularity. Absent significant efficiency improvements, we predict that national set-top box energy use will surpass $40 \mathrm{TWh} / \mathrm{yr}$ by 2010.

The future of telephony energy use is less certain. Energy use may decrease as more efficient mobile phones replace cordless phones and centralized voicemail services replace answering machines. On the other hand, telephony electricity use may increase with the popularity of new cable telephony products, which continuously use electricity for backup power systems.

We identified available efficiency measures as follows:

- better power management for set-top Standby modes

- automatic power-down to Standby for set-tops

- more efficient external power supplies for telephony products

- intelligent battery charging circuitry for telephony products

Implementation of these measures could largely offset the large increases in set-top and telephony energy use expected to materialize in the coming decade. 


\section{TABLE OF CONTENTS}

EXECUTIVE SUMMARY.................................................................................................ii

TABLE OF CONTENTS..................................................................................................vii

LIST OF TABLES ......................................................................................................................ix

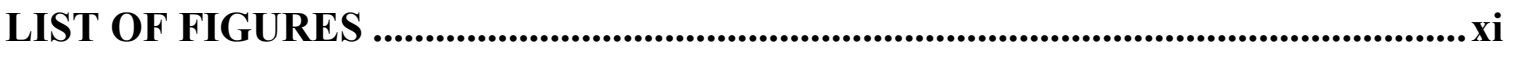

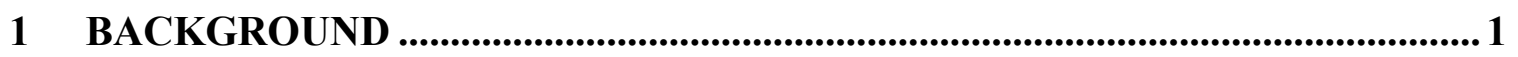

$2 \quad$ APPROACH ...........................................................................................................

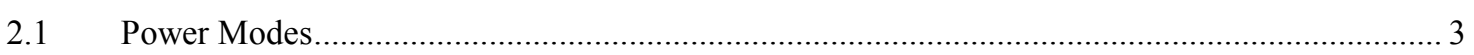

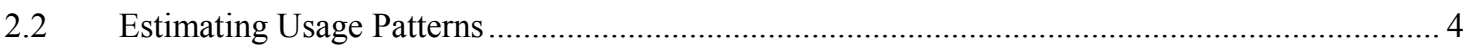

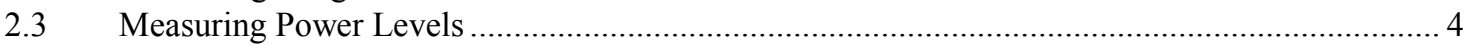

$2.4 \quad$ Estimating Average Annual Unit Energy Consumption (UEC) ..........................................

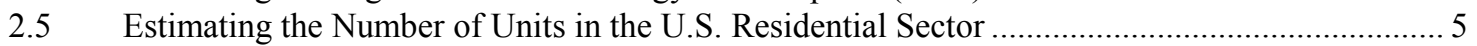

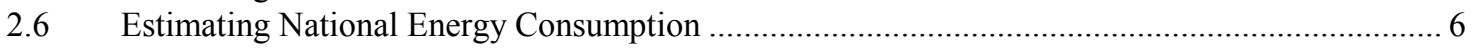

3 SET-TOP ENERGY CONSUMPTION ...................................................................

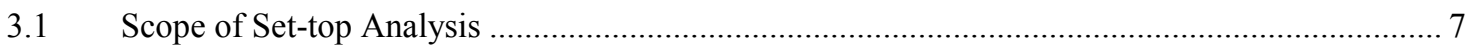

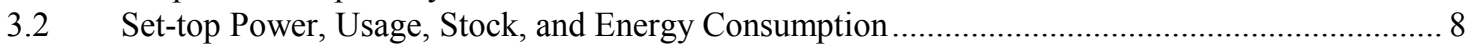

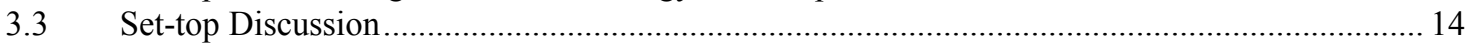

4 TELEPHONY ENERGY CONSUMPTION ...........................................................20

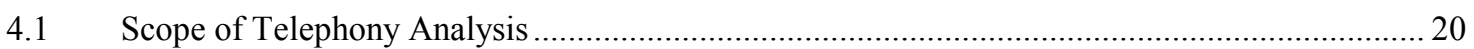

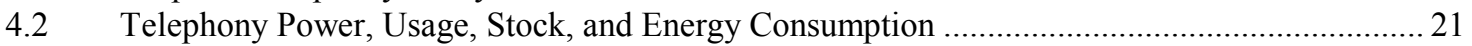

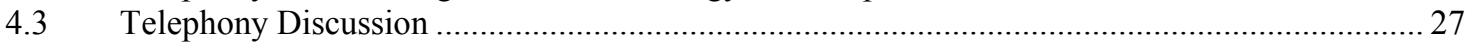

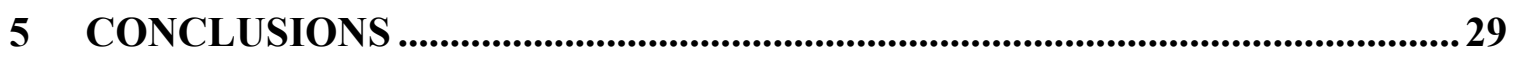

ACKNOWLEDGEMENTS..................................................................................................32

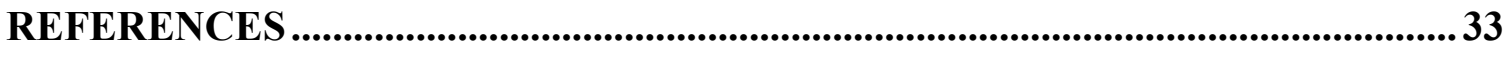

APPENDIX A. SINGLE PHASE POWER MULTIMETER, MODEL PLM-1-LP35;

APPENDIX B. SET-TOP POWER MEASUREMENTS ..........................................377

APPENDIX C. TELEPHONY POWER MEASUREMENTS ...................................... 41 
LBNL-45305 


\section{LIST OF TABLES}

Table 2-1. Common Consumer Electronic Modes ..................................................... 4

Table 3-1. Set-top Usage Patterns ..................................................................... 9

Table 3-2. Average Power Levels for Set-top Boxes ................................................. 11

Table 3-3. Average Annual UEC Values for Set-top Boxes ........................................ 11

Table 3-4. Residential Set-top Stock Estimates ............................................... 13

Table 3-5. National Energy Use of Set-top Boxes in 1999.................................. 13

Table 3-6. Comparison to Other Set-top Energy Use Studies......................................... 14

Table 3-7. Advanced Set-top Box Features ........................................................... 17

Table 4-1. Telephony Usage Patterns ...................................................................... 21

Table 4-2. Average Power Levels for Telephony Products............................................ 24

Table 4-3. Average Annual UEC Values for Telephony Products ................................. 24

Table 4-4. Residential Telephony Stock Estimates............................................... 26

Table 4-5. National Energy Use of Telephony Products in 1999 ................................. 26

Table 4-6. Comparison to Other Telephony Energy Use Studies ................................. 27 
LBNL-45305 


\section{LIST OF FIGURES}

Figure 1-1. Major Electricity End Uses in the U.S. Residential Sector [1] ..................... 1

Figure 3-1. Set-top Box Power Measurements ......................................................... 10

Figure 3-2. Mode Contributions to UEC Values for Set-top Boxes.............................. 12

Figure 3-3. Infrared Photos of an Analog Cable Box in Active and Standby Modes..... 15

Figure 3-4. Infrared Photos of a Satellite Receiver in Active and Standby Modes ........ 16

Figure 3-5. Future U.S. Set-top Box Energy Scenarios............................................. 19

Figure 4-1. Telephony Power Measurements ............................................................ 23

Figure 4-2. Mode Contributions to UEC Values for Telephony Products...................... 25

Figure 5-1. Energy Consumption of Set-tops in the US, 1999.................................... 29

Figure 5-2. Energy Consumption of US Telephony Products in 1999............................. 30 
LBNL-45305 


\section{BACKGROUND}

The U.S. Department of Energy (DOE) maintains an account of how the nation consumes energy to forecast energy use and develop energy policies. The DOE periodically updates their estimates as the U.S. energy demand structure evolves or as new information becomes available. Figure 1-1 shows the DOE's current understanding of major end uses of electricity in the U.S. residential sector.

\section{Figure 1-1. Major Electricity End Uses in the U.S. Residential Sector [1]}

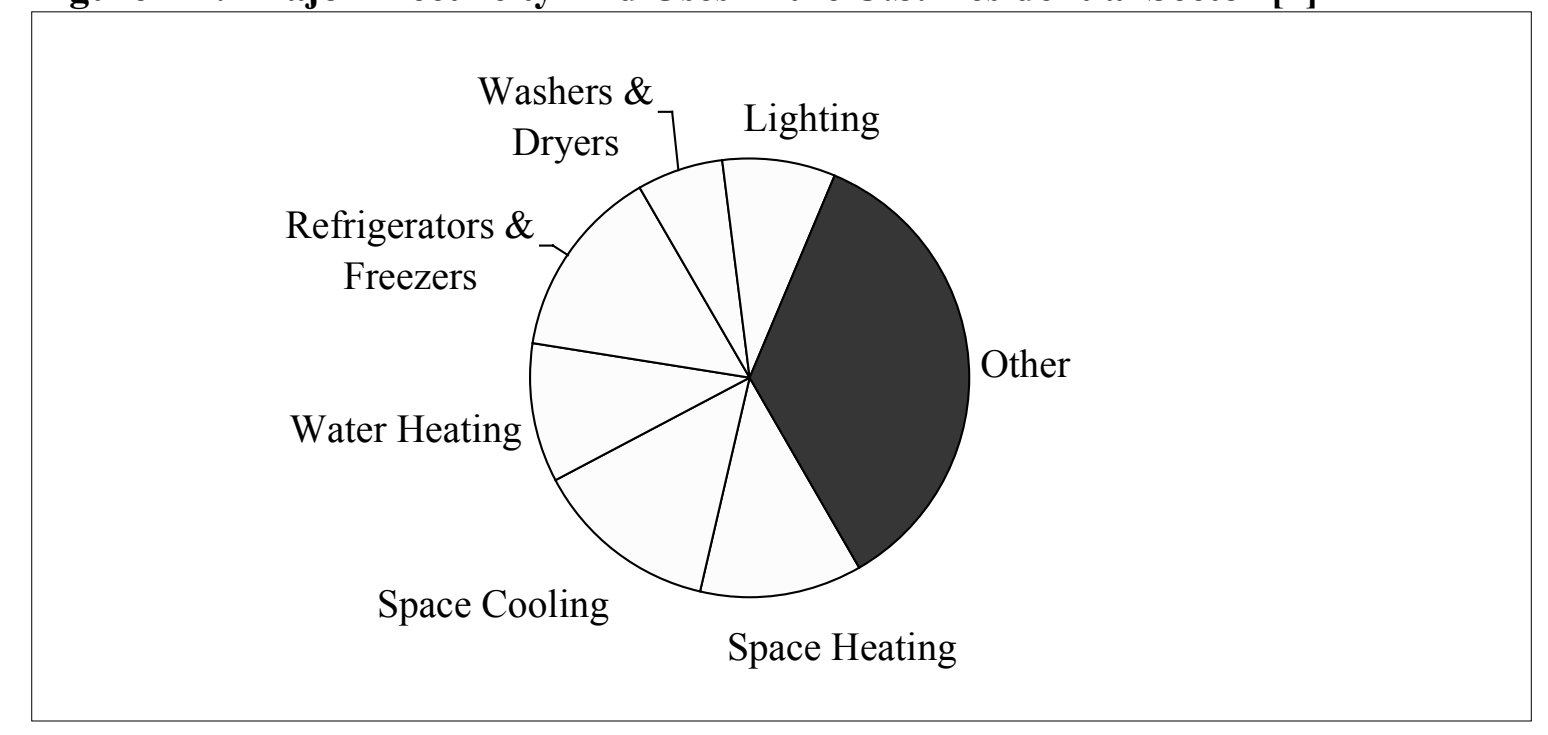

The miscellaneous end-use, depicted in Figure 1-1 as "Other," has recently attracted special attention. Important devices in this end use include consumer electronics, computer equipment, microwave ovens, fans, and pumps. Recent information suggests that miscellaneous electricity use is currently responsible for about one-third of residential electricity consumption and is growing at over $10 \%$ per year [1].

The DOE's Office of Building Technology, State and Community Programs has commissioned several studies with Lawrence Berkeley Lab (LBL) to improve its understanding of the most significant contributors to the miscellaneous end use. They will use this information to improve energy demand forecasts and to explore the feasibility of new efficiency programs directed at products within the miscellaneous end use category.

The first two LBL investigations found that televisions, videocassette recorders, and home audio products account for over $5 \%$ of U.S. residential electricity use [2][3]. This report describes the results of the third investigation in this series: set-top boxes and 


\section{LBNL-45305}

telephony. The main goal of this study is to estimate the 1999 energy consumption of settop boxes and telephony products in U.S. homes.

Previous work in this field includes a 1998 effort by LBL to characterize miscellaneous electricity use. Among the hundred or so products investigated for this early study were some set-top and telephony products [4]. We hope to improve on these estimates through more complete information on power and usage values, and by including more product types. 


\section{APPROACH}

The ideal approach to estimating the national energy use of set-tops and telephony products would entail an extensive metering program involving a statistically representative sample of U.S. homes. Since this approach would be expensive and take years to complete, we resorted to a bottom-up approach that combines direct measurements and survey data.

Our bottom-up estimates of unit energy consumption (UEC) are based on mode-by-mode power requirements and usage patterns. National energy use estimates require, in addition, estimates of how many units are in use in the United States. Our approach can therefore be summarized in the following steps:

1. Identify product types expected to contribute significantly to national energy use

2. For each product, identify the modes expected to contribute significantly to UEC

3. Determine typical usage patterns, i.e. time spent in each mode

4. Collect power measurements for each mode

5. Combine usage and power data to estimate average UEC

6. Determine the number of units (stock) in the U.S. residential sector

7. Combine average UEC values and stock to estimate national energy use

Step 1 of our approach is product dependent, and so will be discussed individually for settops and telephony products in later sections. Below we describe steps 2 through 7 as followed for both set-tops and telephony.

\subsection{Power Modes}

Many consumer electronics operate in different modes (or states) during normal usage. For example, most TVs in the U.S. have two modes: On and Standby (or off). Audio systems have ten or more modes. An accurate estimate of energy consumption requires an estimate of the energy use for each mode. This entails identifying common modes, then determining average power levels and usage for each.

A discrete number of modes can often be defined for any particular device. To allow coverage of a variety of product types, we adopted a rudimentary classification of operating modes to accommodate a variety of consumer electronics. These modes and definitions are given in Table 2-1. 
Table 2-1. Common Consumer Electronic Modes

\begin{tabular}{|ll|}
\hline Mode & Description \\
\hline Active & The unit performs a requested service, e.g. record, play, talk, etc. \\
\hline Charge & The battery charger provides current to the battery \\
\hline Standby & The unit is plugged in and appears off. No current flows to the battery. \\
\hline Disconnected & The unit is unplugged \\
\hline
\end{tabular}

In general, set-top boxes are never Disconnected and do not have batteries to Charge. Therefore, most set-top boxes have two modes: Active and Standby. Telephony products vary significantly. Depending on the unit, significant contributors to unit energy consumption may consist of all or just one of the modes shown in Table 2-1.

\subsection{Estimating Usage Patterns}

Usage data can be difficult to acquire. Unless resources are available for a survey tailored to the needs of the study, the best sources of usage information are previously conducted market research surveys. There are several problems inherent in using such data. For one, market research surveys typically deal with household usage instead of per product usage, but per product usage is required whenever the household owns multiple units [213. Another problem is that market research surveys do not inquire about the states of products during the periods they are not used. These periods account for a major fraction of total electricity use, which are critical for accurate UEC estimates.

\subsection{Measuring Power Levels}

Most of the power measurements in this report were performed by the authors and other Berkeley Lab staff in stores and homes. Retail stores allowed us to perform measurements provided customers were not inconvenienced. Few power measurements were taken at residences because this approach is very intrusive and time consuming.

Consumer electronics power use must be measured with a meter capable of measuring low power levels with high accuracy. For our research, we use a wattmeter custom built for measuring power use as low as 0.1 watts. For more information on the meter used in our power measurements, see Appendix A. 
Power measurements should be taken for every important operational mode. Measurements for this study were conducted according to the following procedure:

1. Identify the operational modes to measure

2. Plug the power cord of the unit into the power meter.

3. Record the standby power consumption before turning the unit on.

4. Record the power consumption of the unit in all other modes.

5. Turn the unit off, and confirm the standby power consumption.

We monitored power draw of all units for about 30 seconds. In general, readings vary by only one or two tenths of a watt within that time. Measurements were recorded by hand on-site, and were later transferred to a computer database for analysis.

\subsection{Estimating Average Annual Unit Energy Consumption (UEC)}

Energy is the product of power and time, and average annual UEC values are typically given in terms of kilowatt-hours per year ( $\mathrm{kWh} / \mathrm{yr})$. We calculate the UEC of a product by determining weighted average power use and then multiplying by the number of hours in a year as follows:

$$
U E C=\left(\sum_{i=1}^{M} \bar{P}_{i} \cdot T_{i}\right) \cdot 8760 h / y r
$$

where $M$ is the number of modes, $\bar{P}_{i}$ is the average power draw of the unit in mode $i$, and $T_{i}$ is the percentage of time that the unit is in mode $i$ such that $\Sigma T_{i}=100 \%$.

\subsection{Estimating the Number of Units in the U.S. Residential Sector}

Two indirect methods can be used to estimate the number of units (stock) of a given product. One method involves using penetration or saturation statistics (defined below) and extrapolating to all U.S. homes . The other involves combining historical sales/shipment data and average product lifetimes in a stock turnover model. For this report, we used the former method, extrapolating penetration statistics to national figures.

The term "penetration" refers to the percentage of homes that own a given device. The term "saturation" is used to express the ratio of units to homes. These numbers can be obtained from a variety of sources, such as market research surveys or service provider subscription records.

Penetration values represent the shares of homes with at least one of the product in question, so penetration alone cannot be used to estimate nationwide stock because 


\section{LBNL-45305}

homes may have multiple units. Estimating stock requires the average number of units owned by each unit-homet as follows:

$$
\text { Stock }=(\text { Households }) \cdot(\text { Penetration }) \cdot(\text { Units } / \text { UnitHome })
$$

This implies that saturation relates to penetration as follows:

$$
\text { Saturation }=(\text { Penetration }) \cdot(\text { Units } / \text { UnitHome })
$$

It is important to note that saturation and penetration are not equivalent unless all appliance owners have only one unit. When saturation statistics are unavailable, as is the case for many products in the miscellaneous end use, penetration statistics may be used to estimate stock - but only in combination with per-home statistics as shown in Equation 2. The missing variable in this equation then becomes units per unit-home, which consumer surveys occasionally report.

\subsection{Estimating National Energy Consumption}

National energy consumption of an appliance is calculated as the product of stock and UEC as follows:

$$
E=(U E C) \cdot(\text { Stock })
$$

where $U E C$ is calculated using Equation 1 and Stock is calculated using Equation 2.

\footnotetext{
${ }^{1} \mathrm{~A}$ "unit-home" is a home that has at least one unit of a given appliance.
} 


\section{SET-TOP ENERGY CONSUMPTION}

This chapter describes our analysis of set-top energy consumption. We begin by describing the types of set-tops widely used in 1999. Following this, we provide the data used in our analysis and the results of our calculations by product type and mode. Finally, we discuss the limits of the analysis and some methods of reducing set-top energy consumption.

\subsection{Scope of Set-top Analysis}

In a broad sense, a set-top is a consumer electronics product designed to output to a TV set. They are so named because they are commonly placed on top of the TV set. For this study, we investigated a range of set-tops to find those most likely to contribute significantly to national residential electricity consumption in 1999. This section describes the set-top boxes we chose to include in this study and their operational modes.

We include the following products in our estimate of 1999 set-top energy consumption: analog cable boxes, digital cable boxes, wireless receivers, and video game consoles. These are the only set-tops for which the installed base exceeded one million units at the beginning of 1999. Following is a description of each of these devices.

Analog cable boxes act as tuners for analog cable TV programming. More than half of cable subscribers use analog cable boxes because they do not have a cableready $T F^{2}$ or desire special programming services.

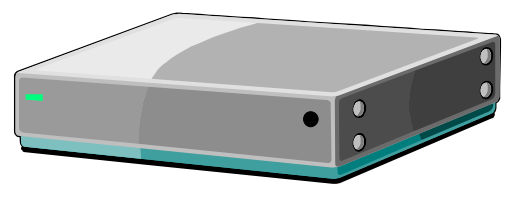
Although available in retail stores, the vast majority of analog cable boxes in U.S. were leased from the cable service providers; thus, cable boxes used without a subscription are not included in this study. Major manufacturers of analog cable boxes include General Instruments, Jerrold, Scientific Atlanta, and Zenith.

Digital cable boxes act as tuners for digital cable TV programming. Since there are several digital TV (DTV) formats, they also convert the digital signal received to one usable by the customer's TV set. To date, there is no

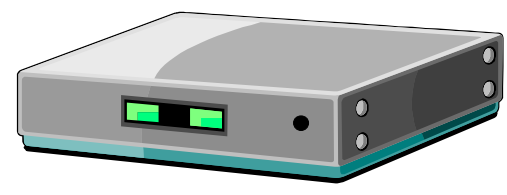
such thing as a "digital-cable ready" TV set, so a box is required for each TV with digital cable programming [E]. In early 1999, the most commonly available digital cable box models were manufactured by General Instruments. At that time, these units were only available through a cable service provider. In the future, consumers are expected to be able to buy digital cable boxes from retail stores [6.7].

\footnotetext{
${ }^{2}$ TVs that are not cable-ready display only UHF and VHF frequencies.
} 
Wireless receivers are set-top boxes used in conjunction with dish antennas to receive wireless TV programming. We include both satellite (DBS and C-band) and terrestrial (wireless cable) systems. To receive wireless services, consumers must buy a receiver and a dish antenna and activate a subscription with a service provider. Each TV set that receives wireless programming requires its own set-top box. Major manufacturers of wireless receiver set-top boxes include Echostar, Hitachi, Hughes, JVC, Proscan, RCA, Sony, and Toshiba.

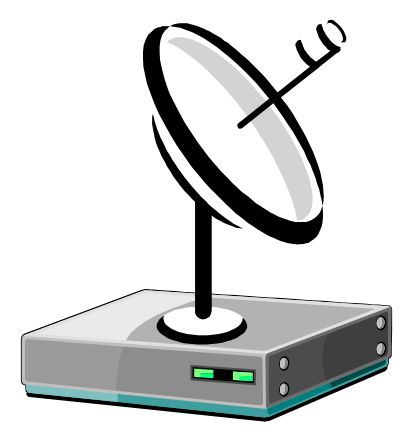

Video game consoles run programs that allow the user to play interactive video games alone or with others. Most video game consoles today read the game program from removable storage media such as CDs or magnetic tape cartridges. Major manufacturers of video game consoles include Nintendo, Sega, and Sony.

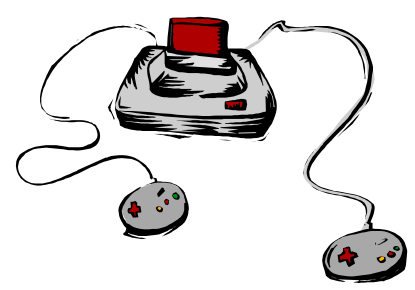

\subsection{Set-top Power, Usage, Stock, and Energy Consumption}

The three factors needed to estimate unit energy consumption are power, usage and stock, as described in Chapter 2. The following sections describe the data used in this study.

\section{Set-top Usage Patterns}

Nearly all set-tops have two main modes, Active and Standby, and a switch to toggle between them. In the Active mode, set-tops receive and/or process information and

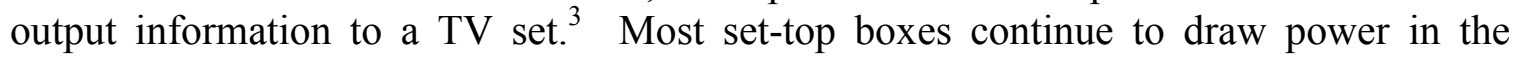
Standby mode to maintain network connections and to allow for remote power-up.

Cable and wireless boxes are Active whenever consumers watch the TV to which they are connected. We therefore derived usage patterns for these devices from TV watching patterns. The average consumer spends about 5.5 hours per day ( $22 \%$ of the time) watching TV programming on the primary TV [2]. Video game consoles are used to play video games about $1 \%$ of the time [8. Table 3-1 shows the usage profiles we used for this study.

\footnotetext{
${ }^{3}$ This activity occurs even when the TV set is not on.
} 
Table 3-1. Set-top Usage Patterns

\begin{tabular}{|lcc|}
\hline Type of Set-top & $\begin{array}{c}\text { Standloy } \\
\text { Time }\end{array}$ & $\begin{array}{c}\text { Active } \\
\text { Time }\end{array}$ \\
\hline Cable, Analog & $78 \%$ & $22 \%$ \\
\hline Cable, Digital & $78 \%$ & $22 \%$ \\
\hline Wireless Receiver & $78 \%$ & $22 \%$ \\
\hline Video Game Console & $98 \%$ & $2 \%$ \\
\hline
\end{tabular}

Note that the Active usage depicted in Table 3-1 includes only time during which the user is present and enjoying the benefits of the box; however, additional Active usage occurs whenever a unit remains on after the TV is switched off. To gain some information about this behavior, we conducted a brief survey of lab staff. Of 35 respondents, eight owned cable or wireless boxes and six owned video game consoles. Of the cable and wireless box owners, half left the units on when they were not being used, and half turned them off, while all video game owners responded that the device was always off unless it was being used. We will not include this behavior in our estimates, but will discuss it later in this chapter.

\section{Set-top Power Measurements}

We measured a sample of about 100 set-top boxes. Measurements of wireless receivers and video game consoles were recorded at retail shops, and therefore represent the equipment currently being sold. A variety of older and newer cable boxes were measured at cable service provider offices and warehouses. About half of the sample was collected in California, and the other half in Washington DC. No conscious effort was made to select a representative sample of manufacturers or quality levels.

Most set-tops were not connected to the network (cable or wireless antenna) during power measurements. Spot measurements of cable boxes connected and disconnected showed no difference in power between the two states. Based on spot measurements of wireless receivers, we estimated that wireless antennas require 3 to 4 watts each. In this study, we use a value of 3.6 watts per antenna.

Figure 3-1 shows the range and mean of the power values collected for this study. For a complete list of the set-top power data collected for this study, see Appendix B. 
Figure 3-1. Set-top Box Power Measurements

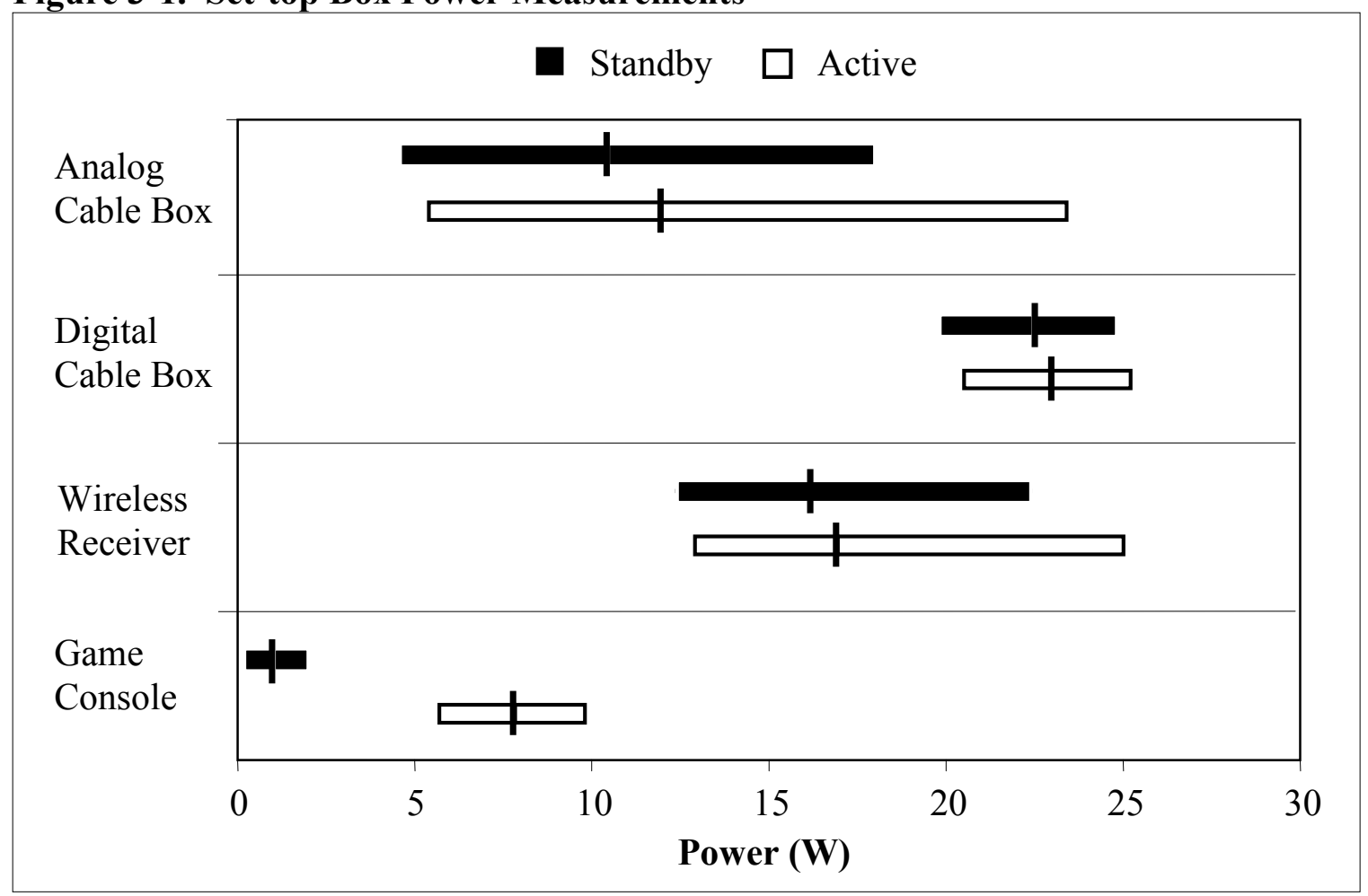

According to our measurements, digital cable boxes draw significantly more power than any other set-top box. Current models draw between 20 and 25 watts in both Active and Standby modes.

We found a wider range in power needs for analog cable and wireless boxes. All of the analog cable boxes we measured used between 5 and 25 watts in both modes, while wireless boxes required 12 to 25 watts.

Some video game consoles used no power in Standby mode, while a few of the older units dissipated power through external power supplies. Active power requirements for video game consoles were also very low, ranging from 5 to 10 watts.

Table 3-2 shows the average Standby and Active power levels derived from our database of power measurements. 
Table 3-2. Average Power Levels for Set-top Boxes

\begin{tabular}{|lccc|}
\hline Type of Set-top & N* $^{*}$ & $\begin{array}{c}\text { Standlby } \\
\text { (watts) }\end{array}$ & $\begin{array}{c}\text { Active } \\
\text { (watts) }\end{array}$ \\
\hline Cable, Analog & 42 & 10.5 & 11.9 \\
\hline Cable, Digital & 5 & 22.3 & 23.0 \\
\hline Wireless Receiver & 30 & 16.2 & 16.9 \\
\hline Video Game Console & 12 & 1.0 & 7.8 \\
\hline
\end{tabular}

$* \mathrm{~N}=$ number of units in the database

While the number of digital cable boxes and video games in our sample is smaller than one might desire for an analysis of this type, very few models of these products were available in 1999. Digital cable boxes were a new product at the time, and we were able to find only five models. Video game consoles are not a new product, but the dominance of two or three major video game manufacturers with only one model each ensures that only a few new models are on the market at any given time.

\section{Average Unit Power and Energy Consumption Estimates for Set-tops}

Using the above usage patterns (Table 3-1) and average power levels (Table 3-2), average UEC values were calculated using Equation 1. Table 3-3 shows the average annual energy consumption of set-top boxes and the portion of the total energy consumption attributable to the Active and Standby modes.

\section{Table 3-3. Average Annual UEC Values for Set-top Boxes}

\begin{tabular}{|lccc|}
\hline Type of Set-top & $\begin{array}{c}\text { Standlby } \\
(\mathrm{kWh} / \mathrm{yr})\end{array}$ & $\begin{array}{c}\text { Active } \\
(\mathrm{kWh} / \mathrm{yr})\end{array}$ & $\begin{array}{c}\text { Total } \\
\text { UEC } \\
(\mathrm{kWh} / \mathrm{yr})\end{array}$ \\
\hline Cable Box, Analog & 72 & 23 & 95 \\
\hline Cable Box, Digital & 150 & 44 & 200 \\
\hline Wireless System & 110 & 33 & 140 \\
\hline Game Console & 9 & 1 & 10 \\
\hline
\end{tabular}

NOTE: Figures may not add due to rounding. 
Figure 3-2 summarizes our findings and indicates the portions of energy use attributable to each mode.

Figure 3-2. Mode Contributions to UEC Values for Set-top Boxes

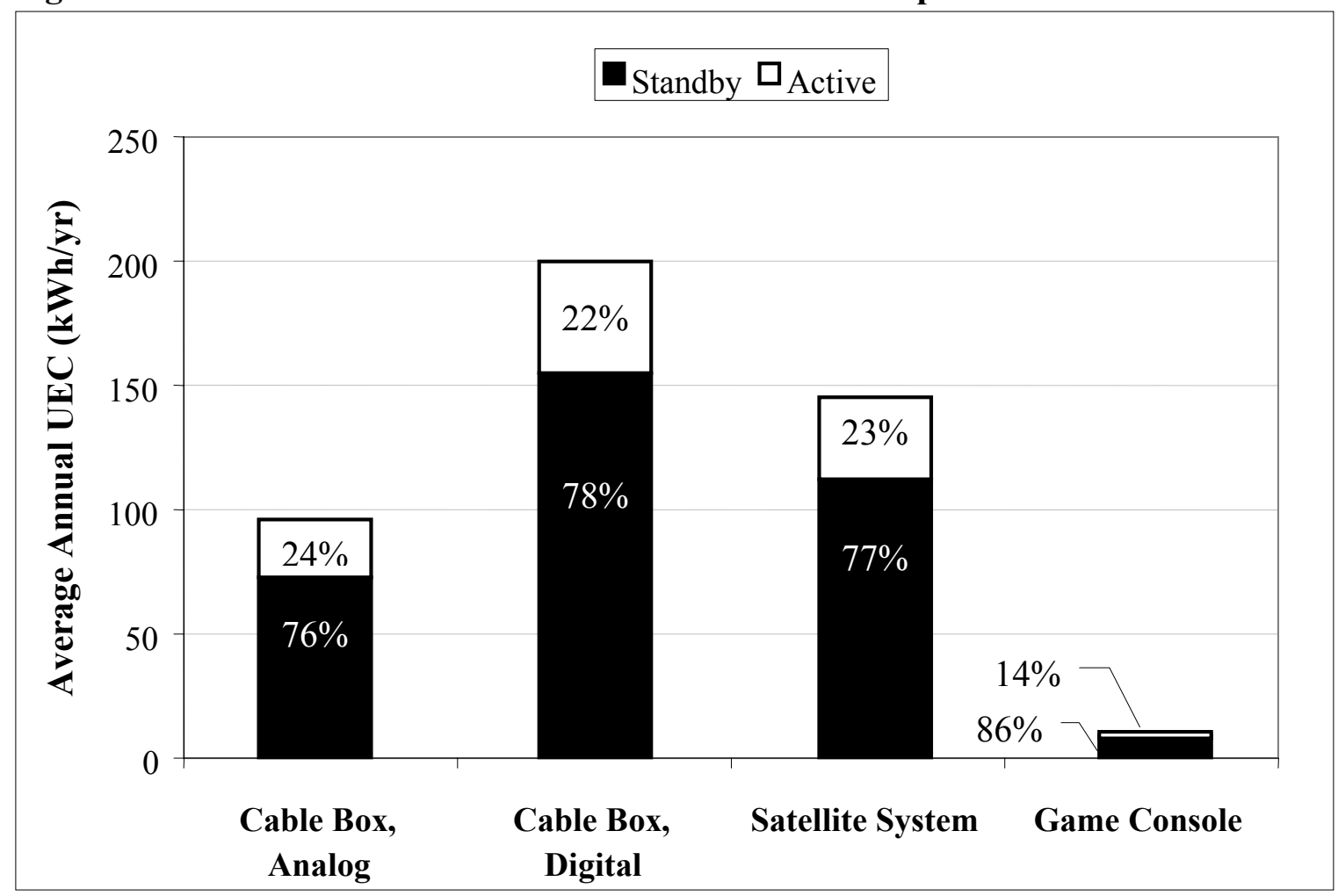

According to these numbers, $75 \%$ of total set-top electricity use occurs during the Standby mode.

\section{Set-top Stock Estimates}

Estimating national energy consumption from UEC values demands the number of units in the U.S. We estimated the number of cable and wireless boxes based on the number of subscribers, and estimates of the number of boxes per subscriber. A 1999 market research survey provided video game console penetration values and average number of units per home. Final stock estimates are shown in Table 3-4 
Table 3-4. Residential Set-top Stock Estimates

\begin{tabular}{|lcccc|}
\hline Type of Set-top & Penetration & $\begin{array}{c}\text { Units per } \\
\text { Unit-Home }\end{array}$ & Saturation & $\begin{array}{c}\text { Total Number of } \\
\text { Units in the U.S. } \\
\text { (millions) }\end{array}$ \\
\hline Analog Cable [j]c & $41 \%$ & 1.05 & $43 \%$ & 45 \\
\hline Digital Cable [10] & $3.7 \%$ & 1.00 & $3.7 \%$ & 3.8 \\
\hline Wireless Receiver [11] & $13 \%$ & 1.00 & $13 \%$ & 13 \\
\hline Video Game Console [12] & $41 \%$ & 1.27 & $52 \%$ & 54 \\
\hline
\end{tabular}

a. Values in italics estimated by the authors.

b. Based on 104.2 million U.S. households in 1999 13

c. Actual reported penetration of $45 \%$ minus digital cable subscribers.

\section{National Set-top Energy Consumption Estimates for 1999}

Using UEC values (Table 3-3) and stock data (Table 3-4), we used Equation 4 to calculate national energy consumption of set-top boxes in 1999. Table 3-5 summarizes our estimates of national set-top energy use and the contributions of each product to total U.S. residential electricity consumption.

Table 3-5. National Energy Use of Set-top Boxes in 1999

\begin{tabular}{|lcccc|}
\hline Type of Set-top & $\begin{array}{c}\text { Standby } \\
(\mathrm{TWh} / \mathrm{yr})\end{array}$ & $\begin{array}{c}\text { Active } \\
(\mathrm{TWh} / \mathrm{yr})\end{array}$ & $\begin{array}{c}\text { Total Product } \\
\text { Energy Use } \\
(\mathrm{TWh} / \mathrm{yr})\end{array}$ & $\begin{array}{c}\text { Share of U.S. } \\
\text { Residential } \\
\text { Electricity Use }^{\mathrm{a}}\end{array}$ \\
\hline Cable Box, Analog & 3.2 & 1.0 & 4.3 & $0.37 \%$ \\
\hline Cable Box, Digital & 0.6 & 0.2 & 0.7 & $0.07 \%$ \\
\hline Wireless System & 1.4 & 0.4 & 1.9 & $0.16 \%$ \\
\hline Game Console & 0.5 & 0.1 & 0.5 & $0.05 \%$ \\
\hline Total Energy Use & $\mathbf{5 . 7}$ & $\mathbf{1 . 7}$ & $\mathbf{7 . 4}$ & $\mathbf{0 . 6 5 \%}$ \\
\hline
\end{tabular}

a. Based on the 1999 residential electricity consumption of 1,143 TWh 13 


\subsection{Set-top Discussion}

\section{Limitations of the Set-top Analysis}

We did not consider the time that set-tops are left on when they are not being used. Based on a non-representative in-house survey, we estimate that cable and wireless boxes are left on about $50 \%$ of the time, while game consoles are almost never left on. Because the power levels of cable and wireless boxes in the Active and Standby states are almost identical, inclusion of this factor would have almost no effect on our final results $(+4 \%)$.

Set-top boxes sometimes download and/or upload information during standby mode. Such activity was not investigated for this study. At this time, we do not expect this activity to contribute significantly to unit energy consumption because of the small disparity between Active and Standby power needs. In the future, however, as Standby levels decrease, the relative share of energy use attributable to this activity will increase.

These results are useful only for 1999, and will change dramatically over the next decade. This limitation will be discussed in detail later in this section.

\section{Comparison of Set-top Energy Use Estimates to Other Studies' Estimates}

In 1998, LBL published estimates of electricity use for over one hundred small electrical appliances in the U.S. residential sector, including cable boxes, satellite receivers, and video game consoles. Table 3-6 compares the major results of the current study to the results of this earlier study.

Table 3-6. Comparison to Other Set-top Energy Use Studies

\begin{tabular}{|c|c|c|c|c|c|c|}
\hline & \multicolumn{2}{|c|}{ Analog Cable } & \multicolumn{2}{|c|}{ Wireless Receiver } & \multicolumn{2}{|c|}{ Video Game } \\
\hline & Rosen & Sanchez & Rosen & Sanchez & Rosen & Sanchez \\
\hline Units (millions) & 45 & 44 & 13 & 5.3 & 54 & 64 \\
\hline Avg. UEC (kWh/yr) & 95 & 114 & 143 & 131 & 10 & 24 \\
\hline Total U.S. (TWh/yr) & 4.3 & 5.0 & 1.9 & 0.69 & 0.5 & 1.5 \\
\hline
\end{tabular}

Disparities between these results can be explained as follows. Our average UEC value for analog cable boxes is based on measurements of over 40 boxes while only five units were measured for the Sanchez estimate. Our estimate for the number of wireless boxes is taken from 1999 FCC data [11], while Sanchez relied on shipment data. ${ }^{-}$The Sanchez estimate is significantly lower because it includes only DBS systems, excluding C-band and wireless cable boxes, and because DBS subscriptions have exploded since the 1998 report. The video game discrepancy could not be determined because the source of Sanchez's video game stock estimate is unknown.

\footnotetext{
${ }^{4}$ The 1999 FCC number differs markedly from Nielsen's estimate of 8.5 million subscribers in 1999.
} 


\section{Improving the Energy Efficiency of Set-tops}

Opportunities exist to increase the efficiency of most set-top boxes. Experience has shown that manufacturers do not power down components that are not in use, even during the Standby mode. Manufacturers of set-top boxes are no exception. Excluding video game consoles, only one of the 77 units measured for this study reduced power use by more than $50 \%$ on initiating the Standby mode. On average, the Standby mode of analog cable boxes used only $12 \%$ less power than the Active mode, while digital cable and wireless boxes provided savings of just 2 to 3 percent.

As further evidence of manufacturers' failure to implement power management, we took infrared (IR) photos of set-top boxes in the Active and Standby modes. The IR photos clearly display which components powered down during the Standby modes. We found very little difference between the two sets of pictures. Figure 3-3 shows the temperature profiles of an analog cable box drawing 13.1 watts in Active mode and 12.0 watts in Standby. Figure 3-4 shows the temperature profiles of an advanced satellite set-top box drawing 24.2 watts in Active mode and 22.2 watts in Standby.

\section{Figure 3-3. Infrared Photos of an Analog Cable Box in Active and Standby Modes}

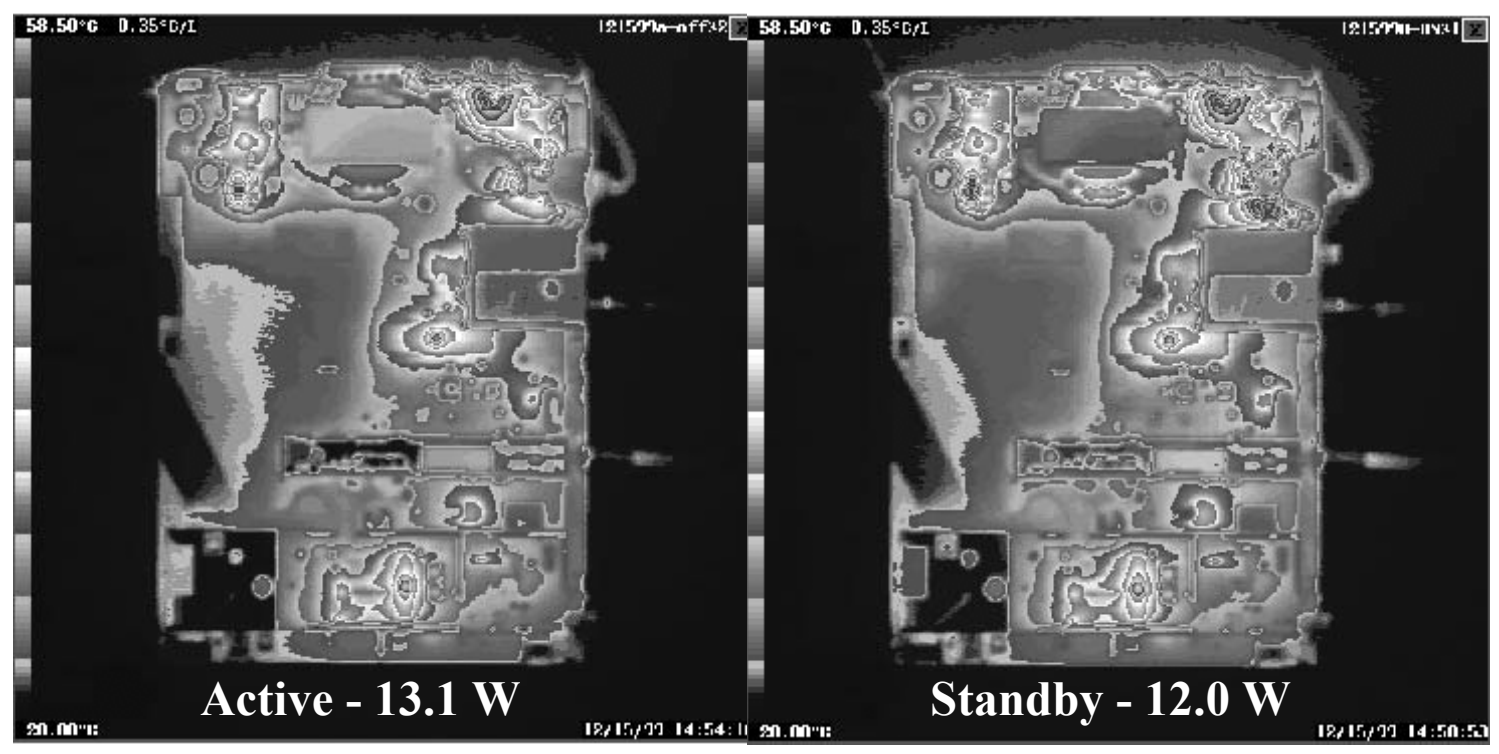


Figure 3-4. Infrared Photos of a Satellite Receiver in Active and Standby Modes

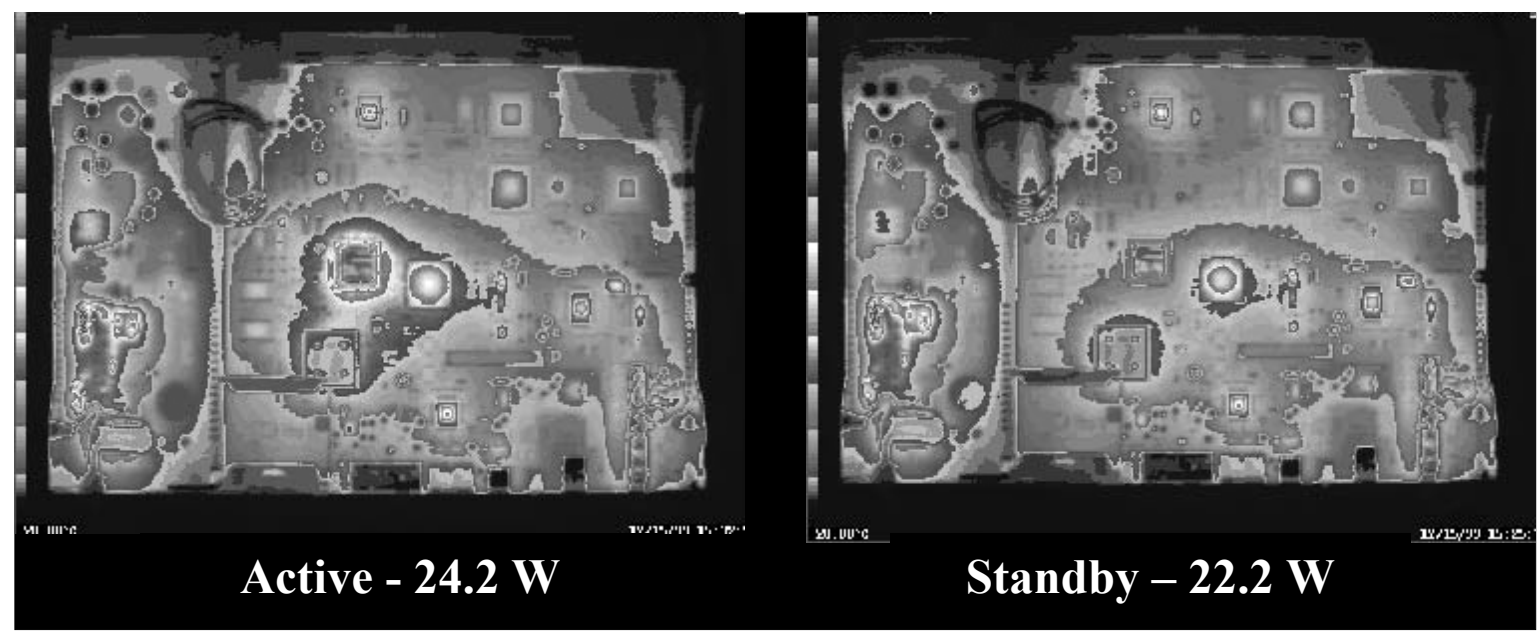

These photos show that the vast majority of components continue to draw power in the Standby mode. Under such conditions, it makes little difference whether these units are turned off or left on at all times. Once manufacturers reduce the Standby power needs of future set-top boxes, further energy savings could be realized by designing set-tops to automatically enter the Standby mode whenever the TV is turned off.

Satellite set-top manufacturers often claim that the box needs significant power to retain the network connection in case the software needs upgrading. There are ways around this issue, as evidenced by some European satellite boxes without such a requirement [14]. This issue should be studied in further detail, particularly given high-growth forecasts for the satellite TV market.

Because digital cable boxes are a relatively new product, power requirements for these units are likely to decrease as digital set-top technology matures. This is because it will be cheaper for manufacturers to use integrated chips designed specifically for set-top box systems than to continue designing their own systems from a larger number of chips. As chips merge, total system power requirements fall, as does manufacturer cost. 


\section{Projected Set-top Energy Use}

This study estimates energy consumption of the four major set-top boxes available in 1999. By mid-2000, new products on the market included digital video recorders, Internet appliances, and digital television converters to name a few. In addition, "multifunction" set-top boxes, such as combination satellite/DTV boxes and video game/Internet boxes, had begun to appear in retail stores. Table 3-7 lists some of the functions and services provided by advanced set-top boxes.

Table 3-7. Advanced Set-top Box Features

\begin{tabular}{|l|l|}
\hline Feature & Function/Service \\
\hline $\begin{array}{l}\text { Pay TV } \\
\text { Programming }\end{array}$ & $\begin{array}{l}\text { Reception of programming beyond what is offered through free local } \\
\text { broadcasts (PBS, ABC, NBC, CBS, Fox). }\end{array}$ \\
\hline $\begin{array}{l}\text { Digital TV } \\
\text { (DTV) }\end{array}$ & Reception and decoding of digital broadcast signals. \\
\hline $\begin{array}{l}\text { Record and } \\
\text { Playback }\end{array}$ & $\begin{array}{l}\text { Recordings of audio and video tracks from radio, TV, and the Internet, } \\
\text { and storage on tapes, CDs, DVDs and internal hard disks. }\end{array}$ \\
\hline Video Game & Video gaming at home or across the Internet \\
\hline Telephony & Telephone calls over cable or a dedicated network. \\
\hline Networking & Communications across the Internet and within the home. \\
\hline
\end{tabular}

Any individual set-top box could have one, two, or all of these features. This makes settop energy projections difficult because the energy use of the unit depends on the type and number of features it provides. Some features require significantly more power than others, and of course more features imply higher energy use. In our projections, we focus on set-tops used for TV programming and DTV reception because we believe that these services will contribute most to future set-top energy use.

The Federal Communications Commission (FCC) has mandated that all broadcast television programming switch from analog to digital by 2007. Should this occur as planned, the number of set-top boxes in the U.S. is expected to skyrocket for the following reasons:

- The 220 million analog TV sets in the United States will be unable to receive TV programming without a set-top box. TV owners have the choice of (1) buying a 


\section{LBNL-45305}

DTV receiver/decoder set-top unit to receive the broadcast digital signal or (2) subscribe to pay TV to receive cable or satellite programming.

- Most digital TV sets sold between now and 2007 will require a set-top for digital conversion and/or high-definition resolutions. While a few DTV models have these features built-in, stand-alone set-top boxes are preferred [15]. Currently, sets labeled high definition TV (HDTV) and standard definition TV (SDTV or DTV) sets have built in digital TV receivers, while those labeled HDTV-compatible or DTV-ready require a set-top decoder box.

- Digital TV sets sold even after 2007 are likely to require a set-top box. Until DTV technology matures and perhaps beyond, it is likely that set-top boxes and TV sets will be analogous to CPUs and monitors: people will prefer separate units so that changes to the set-top hardware can be made without replacing the expensive video display.

Based on these assumptions, it is safe to say that all 100 million TV-homes in the U.S. will have at least one set-top for TV reception by 2010. More likely, each TV will require its own set-top box, bringing the number of set-tops in the U.S. to over 220 million. It is also possible that each TV will have more than one set-top, since there are many different types of set-tops in addition to cable, wireless, and DTV converter boxes. As a result, the number of set-top boxes in the U.S. may exceed 300 million by 2010 .

In addition to the exploding number of set-top boxes, power requirements are also increasing. Digital cable and advanced satellite set-top boxes coming out on the market now use about twice the Active and Standby power of existing cable and satellite set-top boxes. With increased functionality, new set-top boxes are also expected to be Active a larger portion of the time than existing set-tops. In fact, many new set-tops are designed to be Active $100 \%$ of the time, and so do not have an off switch. Because of these developments, we expect the average UEC of set-top boxes to reach between 150 and 300 $\mathrm{kWh}$ per year by 2010 .

Given these predictions, future set-top energy use will certainly rise. The magnitude of this increase depends on the number of units and the average energy consumption of each unit. Today there are just over 60 million set-tops used for TV programming, with an overall average annual UEC of about $100 \mathrm{kWh} / \mathrm{yr}$. We predict that the number of units will reach between 100 and 300 million, and that the average UEC will increase to between 150 and $300 \mathrm{kWh} / \mathrm{yr}$. Figure 3-5 shows some possible set-top energy use scenarios for 2010 based on these predictions. 
Figure 3-5. Future U.S. Set-top Box Energy Scenarios

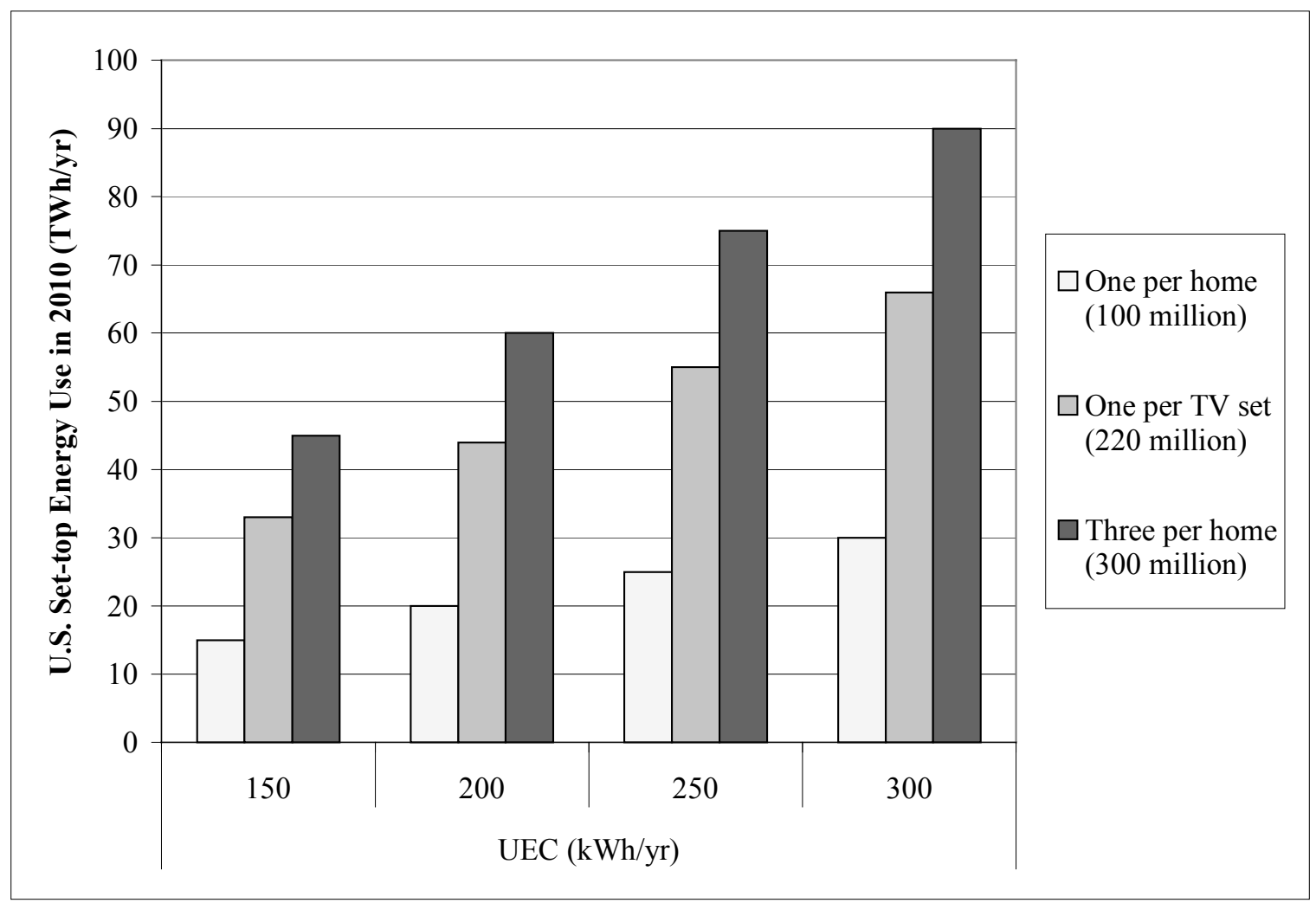

The energy use of set-tops in the U.S. is currently about $7 \mathrm{TWh} / \mathrm{yr}$. According to Figure $3-5$, this end-use will grow to at least $15 \mathrm{TWh} / \mathrm{yr}$ in 2010, and possibly as high as 90 $\mathrm{TWh} / \mathrm{yr}$, depending on the number of units and the average UEC. Given the information available to us at this time and assuming no efficiency improvements, we predict that national set-top energy use will reach at least $40 \mathrm{TWh} / \mathrm{yr}$ by 2010 . 


\section{TELEPHONY ENERGY CONSUMPTION}

Originally, telephones operated on the small amount of power provided through the telephone line. Modern telephony products have advanced features that require hundreds of times more energy than the telephone lines supply. As a result, telephony products now draw power from the electric grid as well.

While telephony energy use has grown over the past couple of decades, total telephony energy use remains small relative to other consumer electronics devices and is not expected to expand substantially. This chapter investigates the total 1999 energy use of the most common residential telephony products in the U.S.

\subsection{Scope of Telephony Analysis}

In this section, we focus on the following products: telephone answering devices (TADs), cordless phones, cordless phone/TAD combination units, and mobile phone chargers.

Telephone answering devices (TADs), commonly known as answering machines, are standalone devices that answer the phone after a designated number of rings, play a pre-recorded message to the caller, and then record a message from the caller. Major TAD manufacturers include AT\&T,

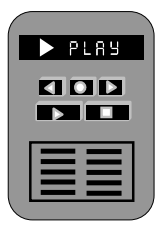
Casio, General Electric (GE) and Panasonic.

Cordless phones provide the same services as a traditional phone except that the handset uses an RF transceiver (instead of a wire) to communicate with the base unit. Major cordless phone manufacturers include AT\&T, Panasonic, Sony, and Toshiba.

Cordless/answering devices are cordless phones with answering machines built into the base unit. Major manufacturers of cordless-phone/answering-

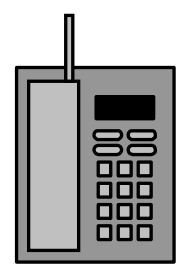
machine combination units include Panasonic, Sony, Toshiba and Uniden.

Mobile phone chargers recharge spent mobile phone batteries. Mobile

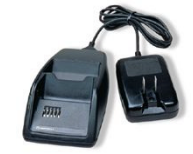
phones with accompanying chargers are typically included as part of wireless phone service contracts. Some of the major mobile phone manufacturers include Audiovox, Ericsson, LG Electronics, Motorola, Nokia, Sony, and Qualcomm. 


\subsection{Telephony Power, Usage, Stock, and Energy Consumption}

This section describes the usage patterns, power requirements, and stock data used to estimate the national telephony energy consumption in 1999.

\section{Telephony Usage Patterns}

Telephony products are Active during talk, record and playback modes. Telephony products with portable (non-corded) handsets contain rechargeable batteries, and so spend some time in Charge mode. The Standby mode of telephony products occurs when the product is plugged in, but is not in the Active or Charge modes. Excluding mobile phone chargers, telephony products are typically never Disconnected.

Obtaining data on how people use their telephony products proved challenging. We were unable to find extensive surveys containing the information we desired. In lieu of this, we conducted our own limited survey to obtain anecdotal evidence of telephony usage. Telephony usage profiles derived from our survey and used in this study are shown in Table 4-1. For simplicity, we exclude the insignificant amount of time that answering machines are recording or playing messages $(<1 \%$ of the time).

Table 4-1. Telephony Usage Patterns

\begin{tabular}{|lcccccc|}
\hline Telephony Product & $\begin{array}{c}\text { Disconnected } \\
\text { Time }\end{array}$ & $\begin{array}{c}\text { Standby } \\
\text { Time }\end{array}$ & $\begin{array}{c}\text { Charge Time } \\
\text { Full }\end{array}$ & $\begin{array}{c}\text { Active } \\
\text { Empty }\end{array}$ & Total \\
\hline Answering Machine & -- & $100 \%$ & -- & -- & -- & $100 \%$ \\
\hline Cordless Telephone $^{\mathrm{a}}$ & -- & $23 \%$ & $65 \%$ & $8 \%$ & $4 \%$ & $100 \%$ \\
\hline Cordless/Answering $^{\mathrm{a}}$ & -- & $23 \%$ & $65 \%$ & $8 \%$ & $4 \%$ & $100 \%$ \\
\hline Mobile Charger $^{\mathrm{b}}$ & $60 \%$ & $38 \%$ & -- & $2 \%$ & -- & $100 \%$ \\
\hline
\end{tabular}

b. For cordless devices, we define Standby as the time when the handset is not on the base unit or in use. We define Charge-full and Charge-empty as the time when the handset is on the base and the battery is fully charged or not fully charged, respectively.

a. For mobile chargers, Standby occurs when the unit is plugged in but not connected to the battery.

Cordless devices and mobile phones require batteries for use. Nearly all 1999 model cordless phones use Nickel Cadmium (NiCd) batteries. NiCd batteries tolerate overcharging; so for cost reasons, manufacturers almost never employ the circuitry needed to sense that a NiCd battery is fully charged. As a result, cordless phone units continue to supply as much current to the battery when it is fully charged as when it is empty. Thus we assume that cordless phones are in the Charge mode whenever the 


\section{LBNL-45305}

handset is on the base. Most mobile phones, on the other hand, use lithium ion (LiI) batteries, which are damaged by overcharging. As a result, most mobile phone chargers return to the Standby mode when the battery is fully charged.f In the following sections, we distinguish between charging that occurs when the battery is full, and when it is empty.

We assume that cordless telephones and cordless/answering devices are used similarly. Also, as mentioned earlier, we exclude the recording and playing back of messages for combination devices. In our survey, we asked cordless phone owners how much time each cordless phone was used (Active), and how much time the handset was on the base (Charge). The average Active time reported by the 36 respondents was $4 \%$, while the average Charge time was $73 \%$. Since NiCd batteries require about twice as much time to charge as to discharge through use, we estimate that the actual charging of the battery takes about $8 \%$ of the time, while the remaining $65 \%$ of charging occurs when the battery is already full.

Battery chargers for mobile phones can be unplugged when they are not charging batteries, but many people leave them plugged in all the time. Of the fifteen mobile phone owners responding to our survey, about half left the chargers plugged in at all times, while the other half unplugged the devices when they were not in use. On average, survey respondents indicated that they left their mobile phone batteries attached to the charger for about 4 hours per day, or $15 \%$ of the time. Since charge rates vary significantly, it would be difficult to determine the portion of this time spent charging the battery (Charge-empty) and the portion spent in the "trickle charge" mode (Charge-full). To avoid lengthy experimentation with a large number of chargers, we assumed that the average mobile phone battery takes about 2 hours to charge and is charged about 50 times per year at the owners residence 7 for a total of 100 hours ( $1 \%$ of the time), in the Chargeempty mode.

\section{Telephony Power Measurements}

We measured over 70 telephony products. Most of the measurements were recorded at retail shops, so our sample represents the stock of equipment being sold at the time of the study. No conscious effort was made to select a representative sample of manufacturers or price points. This raised concerns that the data sample collected was not representative of U.S. stock. However, our measurements showed that there was little variation between units. Power measurements indicated no significant difference in energy requirements for

\footnotetext{
${ }^{5}$ Many chargers "trickle charge" or send current intermittently because unused batteries tend to lose charge over time. We do not include this small amount of current in our calculations.

${ }^{6}$ Most respondents left the handset on the base whenever it was not being used. This is interesting because $\mathrm{NiCd}$ batteries develop what is called a "memory effect", meaning that operating time decreases if they are not discharged completely before each charge.

${ }^{7}$ Mobile phone owners frequently charge their phones in the car.
} 
older and newer products, or for products from different manufacturers. These factors combine to give us some confidence in the validity of our sample. The range and mean value of telephony power measurements collected for this study are shown in Figure 4-1 For a complete list of the power data collected for this study, see Appendix C.

Figure 4-1. Telephony Power Measurements

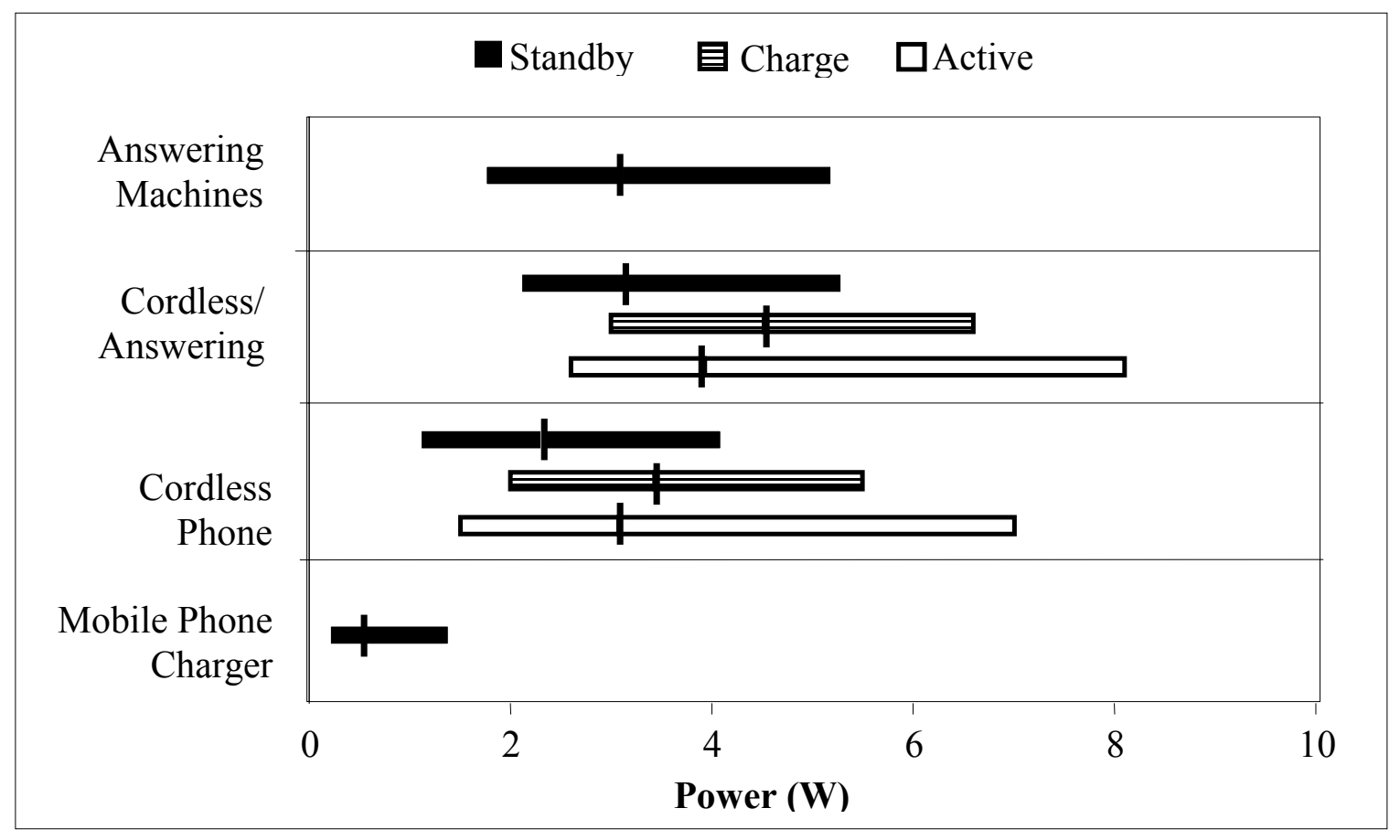

We found that most standalone answering machines use between 2 and 5 watts of power in the Standby mode. The Active mode will be excluded in this study because (1) the disparity between Active and Standby power levels is very small (see Appendix C) and (2) the Active mode accounts for an insignificant portion of time $(<1 \%)$, as previously mentioned.

The cordless devices in our database used 1 to 8 watts in all modes. Because we measured mainly new units that had never been connected to a power source, the Charge values observed represent the Charge-empty power use. We were able to obtain a handful of Charge-full measurements at the lab and in homes, none of which indicated that the flow of current to the battery waned once the battery was fully charged. We expect that this is true of the vast majority of cordless phones, so we used the Charge-empty power level for both modes. 
Mobile phone chargers consist almost exclusively of an efficient external power supply. As a result, they use much less power than do the other telephony products shown here, which need additional power consuming circuitry for a higher level of functionality.

Table 4-2 shows the number of units measured and the average power levels we used in our calculations of national telephony energy consumption.

Table 4-2. Average Power Levels for Telephony Products

\begin{tabular}{|lcccc|}
\hline Telephony Product & N & $\begin{array}{c}\text { Standby Active Charge } \\
\text { (watts) }\end{array}$ & $\begin{array}{c}\text { (watts) } \\
\text { (watts) }\end{array}$ \\
\hline Answering Machine & 27 & 2.9 & -- & -- \\
Cordless Telephone & 20 & 2.3 & 3.1 & 3.4 \\
Cordless/Answering & 21 & 3.1 & 3.9 & 4.4 \\
Mobile Charger & 7 & 0.6 & -- & -- \\
\hline
\end{tabular}

We would have liked to measure more than seven mobile phone chargers; however we found that very few models exist. In addition, the Standby power use of mobile phone chargers does not vary much, so we are confident that the small sample is fairly representative.

\section{Average Unit Power and Energy Consumption Estimates for Telephony}

With the exception of mobile chargers, average UEC values were calculated using Equation 1. For mobile chargers, we calculated the total energy as the sum of the Standby energy use, the energy supplied to the battery, and the transformer losses of the battery charger during the Charge mode. Table 4-3 summarizes our findings.

Table 4-3. Average Annual UEC Values for Telephony Products

\begin{tabular}{|c|c|c|c|c|c|}
\hline \multirow[t]{2}{*}{ Telephony Product } & Standby & $\begin{array}{l}\text { Charge } \\
\text { Full }\end{array}$ & $\begin{array}{l}\text { Charge } \\
\text { Empty }\end{array}$ & Active & Total UEC ${ }^{\mathrm{a}}$ \\
\hline & $(\mathrm{kWh} / \mathrm{yr})$ & $(\mathrm{kWh} / \mathrm{yr})$ & $(\mathrm{kWh} / \mathrm{yr})($ & $\mathrm{kWh} / \mathrm{yr})$ & $(\mathrm{kWh} / \mathrm{yr})$ \\
\hline Answering Machine & 26 & & & & 26 \\
\hline Cordless Telephone & 4.5 & 20 & 2.4 & 1.1 & 28 \\
\hline Cordless/Answering & 6.1 & 25 & 3.1 & 1.4 & 36 \\
\hline Mobile Charger & 1.8 & & $0.5^{\mathrm{b}}$ & & 2.3 \\
\hline
\end{tabular}

a. Figures may not add due to rounding.

b. Assumes the average battery holds $1000 \mathrm{mAh}$ and is charged 50 times per year at 3 hours per charge.

Further assumes that transformer losses do not increase during charging. 
Figure 4-2 summarizes our findings and indicates the portions of energy use attributable to each mode.

Figure 4-2. Mode Contributions to UEC Values for Telephony Products

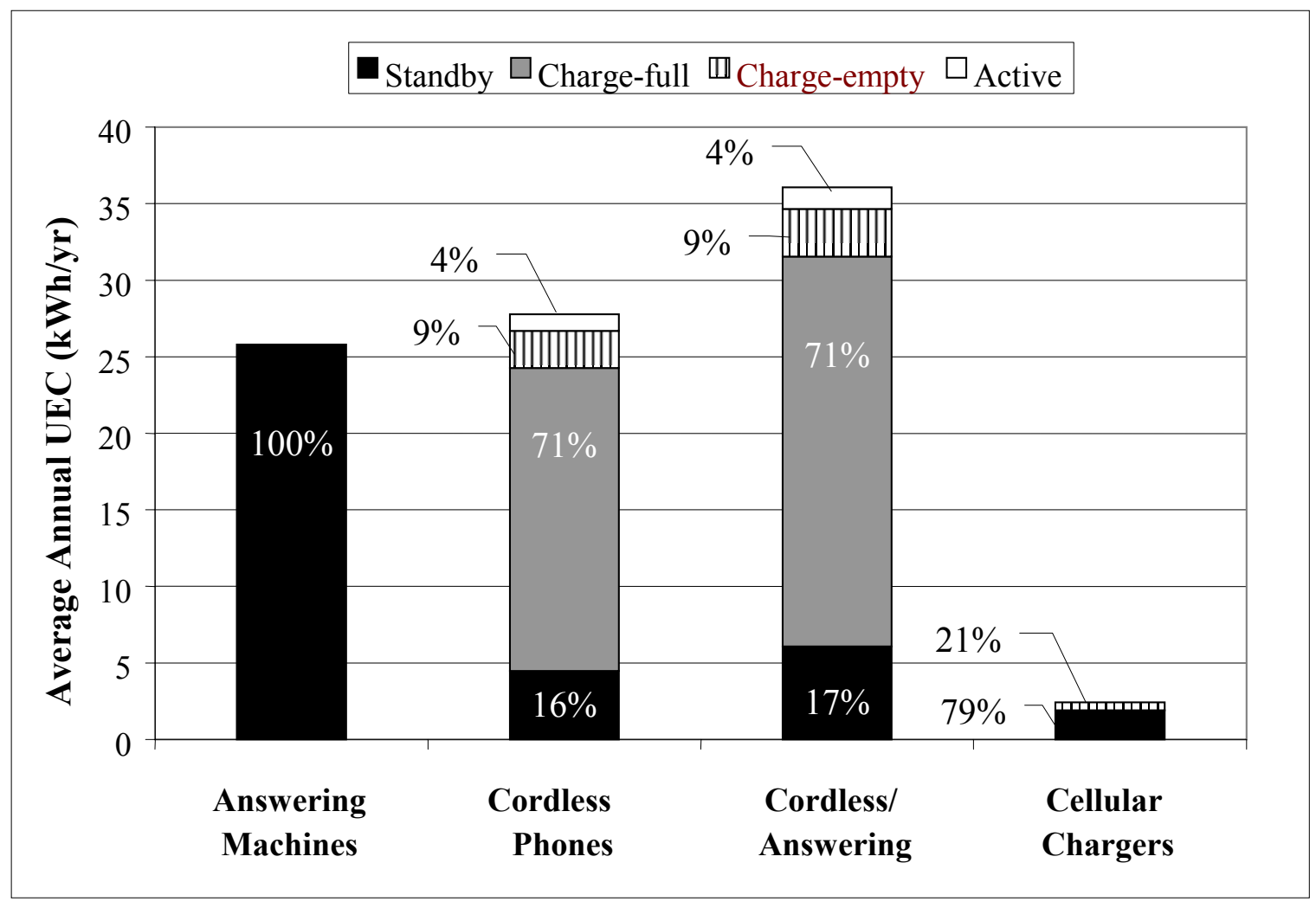

The extremely low UEC of mobile phones may come as a surprise to some. Even though mobile phone chargers are not used as efficiently as they could be $-75 \%$ of mobile charger energy use is wasted during Standby - a mobile phone still uses less than onetenth the energy used by a cordless phone. A mobile phone charger that is consistently unplugged when not in use would require only one-fiftieth the energy of a cordless unit. 


\section{Telephony Stock Estimates}

All telephony stock estimates were based on the results of a 1999 market research survey [12]. Estimates of residential stock are shown in Table 4-4

Table 4-4. Residential Telephony Stock Estimates

\begin{tabular}{|lccc|}
\hline Telephony Product & Penetration & $\begin{array}{c}\text { Units/Unit- } \\
\text { home }\end{array}$ & $\begin{array}{c}\text { Units }^{\mathrm{a}} \\
\text { (millions) }\end{array}$ \\
\hline Answering Machine & $67 \%$ & 1.10 & 77 \\
\hline Cordless Telephone & $73 \%$ & 1.15 & 87 \\
\hline Cordless/Answering & $31 \%$ & 1.08 & 35 \\
\hline Mobile Charger & $43 \%$ & 1.17 & $53^{\mathrm{b}}$ \\
\hline
\end{tabular}

a. Based on 104.2 million households in the U.S. in 1999 [13.

b. The Mobile Telecommunications Industry Association estimated that there were over 70 million mobile phone subscribers in June of 1999 [16, including both commercial and residential mobile phones. This value represents the number of mobile phones in the residential sector.

\section{National Telephony Energy Consumption Estimates for 1999}

Using UEC values (Table 4-3) and the above stock values (Table 4-4), we used Equation 4 to calculate national energy consumption of telephony products as shown in Table 4-5.

Table 4-5. National Energy Use of Telephony Products in 1999

\begin{tabular}{|lcccccc|}
\hline \multirow{2}{*}{ Telephony Product } & Standby $\begin{array}{c}\text { Charge } \\
\text { Full }\end{array}$ & $\begin{array}{c}\text { Charge } \\
\text { Empty }\end{array}$ & \begin{tabular}{c} 
Active \\
\cline { 2 - 5 }
\end{tabular} & $\begin{array}{c}\text { National } \\
\text { Energy } \\
\text { Use }\end{array}$ & $\begin{array}{c}\text { Share of U.S. } \\
\text { Residential } \\
\text { Electricity Use }\end{array}$ \\
\hline Answering Machine & 2.0 & -- & -- & -- & 2.0 & $0.17 \%$ \\
\hline Cordless Phone & 0.4 & 1.7 & 0.2 & 0.1 & 2.4 & $0.21 \%$ \\
\hline Cordless/Answering & 0.2 & 0.9 & 0.1 & 0.0 & 1.3 & $0.11 \%$ \\
\hline Mobile Charger & 0.1 & -- & 0.03 & -- & 0.1 & $0.01 \%$ \\
\hline Total & $\mathbf{2 . 7}$ & $\mathbf{2 . 6}$ & $\mathbf{0 . 3}$ & $\mathbf{0 . 1}$ & $\mathbf{5 . 8}$ & $\mathbf{0 . 5 1 \%}$ \\
\hline
\end{tabular}

a. Based on the 1999 residential electricity consumption of 1,143 TWh 13 


\subsection{Telephony Discussion}

\section{Limitation of the Telephony Analysis}

We were unable to find information regarding telephony product usage, and so based usage values on the results of a short in-house survey, which is unlikely to be representative of U.S. society at large. However, inaccuracies in our usage estimates will not have large effects on the total telephony energy consumption estimate because power requirements do not vary significantly between modes. Even if telephony products were always in the lowest available power modes, telephony energy use would drop by only $20 \%$ to $4.7 \mathrm{TWh} / \mathrm{yr}$. On the other extreme, were TADs always Active, and cordless and mobile phones always charging, telephony energy use would be about $40 \%$ higher than our estimate. We are confident that our usage estimates provide reasonable results.

Power levels used in this study represent the stock of telephony products currently sold because most power measurements were taken in retail stores. Our sample was not large enough to conduct a proper statistical analysis; however, anecdotal evidence suggests that the power levels of older units do not differ from newer units.

Only seven mobile telephone chargers were measured for this study. We think that this is acceptable for two reasons: (1) these units account for a relatively small portion of telephony energy consumption, and (2) according to sales staff, the units we measured are currently the most popular.

\section{Comparison of Telephony Energy Use Estimates to Other Studies' Estimates}

In 1998, LBL published estimates of electricity use for over one hundred small electrical appliances in the U.S. residential sector, including cordless phones and answering machines. Table 4-6 shows the major results of this study alongside the results of this earlier study.

Table 4-6. Comparison to Other Telephony Energy Use Studies

\begin{tabular}{|lccccc|}
\hline & \multicolumn{2}{c}{ Answering Machine } & & \multicolumn{2}{c|}{ Cordless Phone } \\
\cline { 2 - 3 } & Rosen & Sanchez & & Rosen & Sanchez \\
\hline Units (millions) & 77 & 66 & 87 & 61 \\
\hline Avg. UEC (kWh/yr) & 26 & 29 & 28 & 25 \\
\hline Total U.S. (TWh/yr) & 2.0 & 1.9 & 2.4 & 1.5 \\
\hline
\end{tabular}

While our answering machine energy use estimate is comparable to that of Sanchez. Our cordless phone energy use estimate is $60 \%$ higher. This is mainly attributable to an increase in the number of cordless phones in U.S. homes from 1995 to 1999. 


\section{LBNL-45305}

\section{Improving the Energy Efficiency of Telephony}

Many phones get all the power they need from the phone line, using power only when the phone rings or when the handset is away from the base. Newer telephony products use extra power for functions like recording messages, charging batteries, and sending and receiving radio frequency signals. With proper design, phones could function without extra power when these advanced functions are not being performed. Were manufacturers of powered telephony products to take advantage of this opportunity, telephony energy use could be reduced by about $90 \%$.

While available technologies could reduce telephony energy use by as much as $90 \%$ or more, they would require some revolutionary changes in residential telephony design. Until these efficiency improvements become cost-effective, other low-cost or no-cost energy-saving techniques should be considered. For example, current telephony products often use inefficient external power supplies with no-load losses of about $1 \mathrm{~W}$. The replacement of these $1 \mathrm{~W}$ power supplies with commonly available $0.5 \mathrm{~W}$ units, such as those used for mobile phone chargers, would reduce telephony energy consumption by $15 \%$ to $20 \%$.

Implementing more advanced battery charging technologies would also reduce telephony energy consumption significantly. According to our estimates, over $40 \%$ of telephony energy consumption occurs during overcharging. Phones manufactured with smartcharging circuitry would use about $25 \%$ less energy than existing products.

\section{Projected Telephony Energy Use}

Assuming that no new plug-in standalone telephony products emerge in the coming decade, we think that telephony energy use will remain steady or even decline in the future, as increasing numbers of Americans purchase mobile phones. Since mobile phones are battery-powered, the phone itself is designed to be as energy efficient as possible. In addition, mobile phone battery chargers are already more efficient than other types of battery chargers because they use efficient power supplies and do not overcharge the batteries.

One development that has the potential to prove this prediction false is the digital cable telephone market. Currently, cable service providers offer telephone services over the cable TV network. Because the cable network is not powered (as is the telephone network), cable telephones rely on battery backup in the event of a power outage. These battery chargers are plugged in $100 \%$ of the time, consuming 6.0 watts, for an annual UEC of over $50 \mathrm{kWh} / \mathrm{yr}$.

\footnotetext{
${ }^{8}$ There is ongoing research to create LiI batteries that tolerate overcharging. If this research is successful, future LiI battery chargers may become as inefficient as $\mathrm{NiCd}$ battery chargers.
} 


\section{CONCLUSIONS}

This study found that cable boxes, wireless receivers, and video game consoles accounted for $7.4 \mathrm{TWh}(0.7 \%)$ of U.S. residential electricity consumption in 1999 . Of the four types of set-tops studied, digital cable boxes had the highest individual UEC at $200 \mathrm{kWh} / \mathrm{yr}$, while analog cable boxes currently use the most energy nationwide (4.3 TWh/yr). We also found that Standby accounts for about $75 \%$ of total set-top energy use and that this electricity could be significantly reduced with simple efficiency techniques. Figure 5-1 summarizes our findings.

Figure 5-1. Energy Consumption of Set-top Boxes in 1999

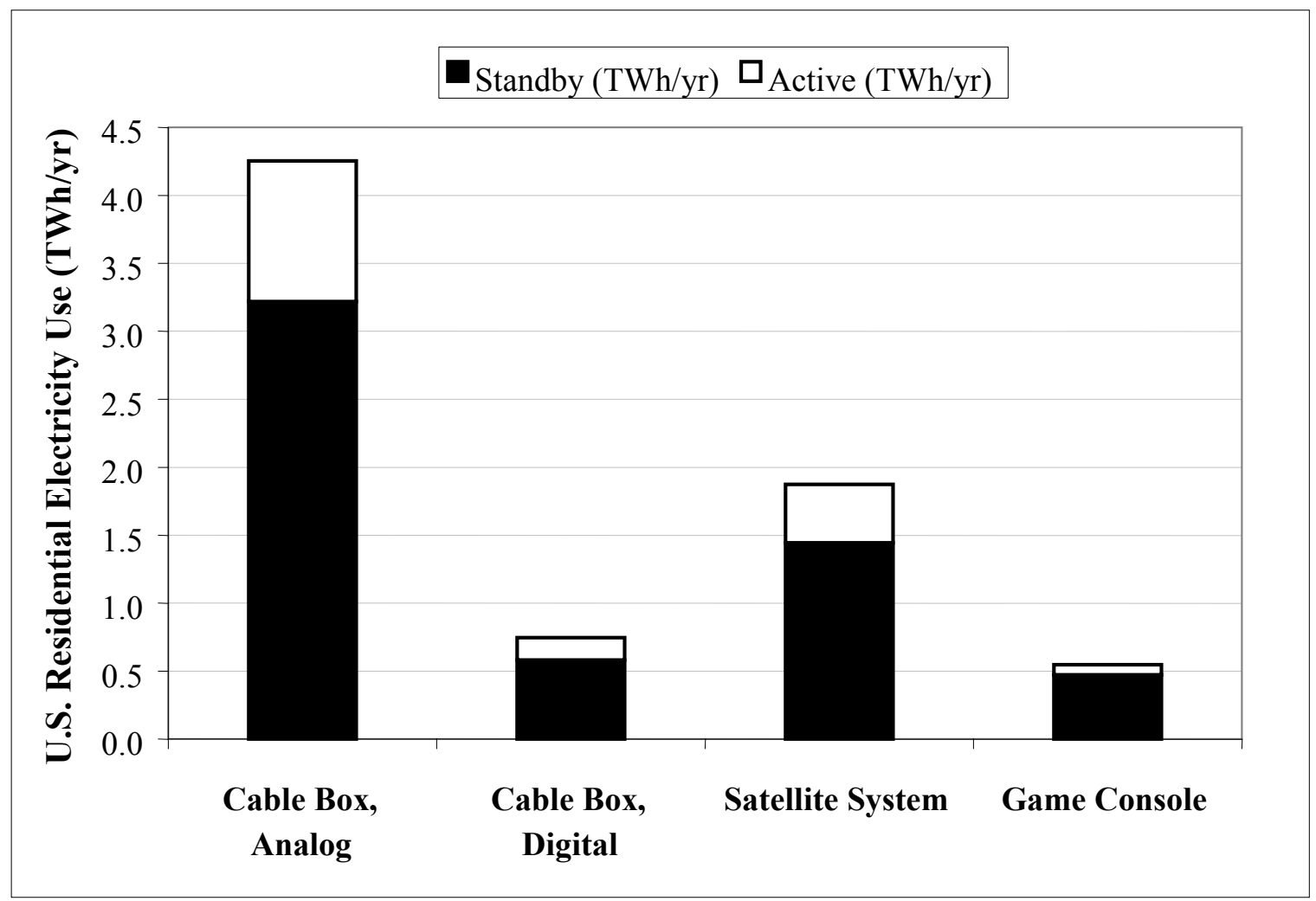

Today there are just over 60 million cable and satellite set-top boxes with an overall average annual UEC of about $100 \mathrm{kWh} / \mathrm{yr}$. We predict that by 2010 , the number of settops will reach between 100 and 300 million, and that the average UEC will increase to between 150 and $300 \mathrm{kWh} / \mathrm{yr}$. As a result, we estimate that national set-top energy consumption will grow to at least $15 \mathrm{TWh} / \mathrm{yr}$ in 2010, and possibly as high as $90 \mathrm{TWh} / \mathrm{yr}$, depending on the number of units and the average UEC. Given the information available at this time and assuming no efficiency improvements, we predict that national set-top energy use will reach at least $40 \mathrm{TWh} / \mathrm{yr}$ by 2010 . 
Cordless phones, answering machines, combination units, and mobile phones accounted for nearly 6 TWh $(0.5 \%)$ of U.S. residential electricity consumption in 1999. Figure 5-2 shows the energy consumption of telephony products in the U.S. in 1999.

Figure 5-2. Energy Consumption of Telephony Products in 1999

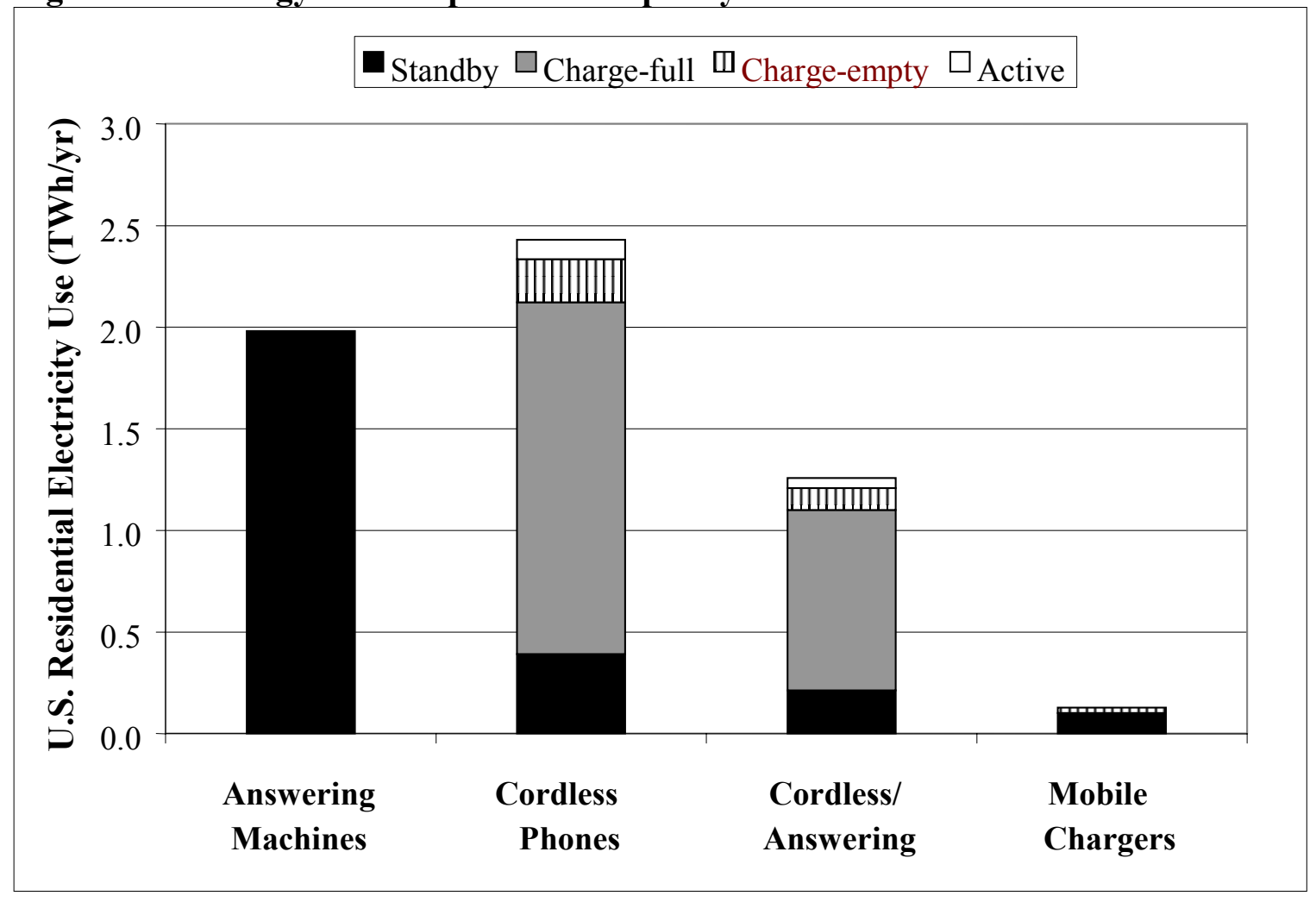

Answering machines consume nearly $2 \mathrm{TWh} / \mathrm{yr}$, almost all (99\%) of which occurs during the Standby mode. Together, cordless telephones and cordless/answering combination units use $3.7 \mathrm{TWh} / \mathrm{yr}$. Less than $20 \%$ of this electricity use occurs during the times the phone is being used or recharging. Mobile phones are significantly more efficient than cordless phones.

The future of home telephony products is uncertain. The number of mobile phones will continue to increase, but we expect that the energy required for battery charging will decrease or even disappear, as mobile phones become more efficient and alternative power sources replace batteries.

The data presented in this report comprise a good estimate of the energy use for set-top boxes and telephony products in 1999. However, because technologies involved in the manufacture and use of set-tops and telephony products are changing rapidly, great care must be taken in extrapolating from the data presented here to future energy use. Recent 
technological and regulatory changes have enabled the convergence of several heretoforeseparate information distribution networks. The result of these converging networks is the convergence of several communications devices, including set-tops and telephony, into a new generation of advanced set-top boxes. These set-top boxes are likely to result in new and increased energy demands. 


\section{ACKNOWLEDGEMENTS}

Thanks to Jon Koomey at LBNL and Jim Brodrick at the Department of Energy for comments and suggestions.

This work was supported by the Assistant Secretary for Energy Efficiency and Renewable Energy of the U.S. Department of Energy under Contract No. DE-AC03-76SF00098. 


\section{REFERENCES}

1 U.S. Department of Energy, Energy Information Administration (EIA). 2000 Annual Energy Outlook. Washington, D.C.: U.S. DOE EIA, 1999.

2 Rosen, Karen B. and Alan K. Meier. National Energy Consumption of Televisions and Videocassette Recorders. LBNL-42393. Berkeley, CA: Lawrence Berkeley National Laboratory, March 1999.

3 Rosen, Karen B. and Alan K. Meier. National Energy Consumption of Home Audio Products in the U.S. LBNL-43468. Berkeley, CA: Lawrence Berkeley National Laboratory, November 1999.

4 Sanchez M., J. Koomey, M. Moezzi, A. Meier, and W. Huber. Miscellaneous Electricity Use in the U.S. Residential Sector. LBNL-40295. April 1998.

5 Merritt, Rick. Kennard Calls For Cable-Ready DTV By April. EE Times. January 10, 2000. (http://www.techweb.com/wire/story/TWB20000110S0007)

6 Anonymous. Consumers to Get Choice of Set-tops. ZDNet News (Reuters). May 13, 1999. (http://www.zdnet.com/zdnn/stories/news/0,4586,2258577,00.html)

7 FCC. Telecommunications Act of 1996, Section 304: Commercial Availability of Navigation Devices. CS Docket No. 97-80. 1997.

8 Media Dynamics. TV Dimensions '98. Media Dynamics, Inc.: New York, NY. 1998. 9 Television and Cable Factbook, 1997.

10 Strategis Group, Press Release, April 5, 1999.

11 FCC. Annual Assessment of the Status of Competition in Markets for the Delivery of Video Programming. CS Docket No. 99-230. 1999.

12 CEMA, CE Product Ownership, April 1999.

13 DOE/EIA. Annual Energy Outlook 2000, Appendix A, Table 4. 1999.

14 Zandelin, S. Reduction of Standby Energy Use in Set-top Boxes in the United States and the European Union. ISSN 0282-1990. 2000.

15 De Sonne, Marcia L. HDTVs - It's Where the Buyers Are: Consumer Interest, Set Availability, Set-Top Converters. National Association of Broadcasters Technology \& Convergence Business/Information Briefs. May 1998.

16 Federal Communications Commission. Trends in Telephone Service. March 2000. 
LBNL-45305 


\section{APPENDIX A. SINGLE PHASE POWER MULTIMETER PLM-1-LP}

Electronic Product Design, Inc., 2145 Debra Drive, Springfield, Oregon 97477

The Single Phase Power Multimeter (model PLM-1-LP) is an electronic instrument used to measure parameters associated with power consumption by an electrical load that is normally operated from a 50 or 60 hertz power line. Power is supplied to the load via a permanent power cord exiting the rear panel and a $15 \mathrm{amp}, 120$-volt outlet on the front panel. An internal 0.1 -ohm shunt, wired in series with the neutral wire, senses the current. The voltage is measured between the hot and neutral wires. Power is provided to the measuring electronics via the same power cord. Current is limited to three amps RMS with an inline, 3 amp, slow-blow fuse accessible at the rear panel.

The Single Phase Power Multimeter measures; true RMS voltage and current; true power; and peak voltage, current, and power. This meter also calculates Power-Factor, VoltAmps, and VARS. In addition the PLM-1-LP accumulates Time and Watt-Hours.

Display information, time, and accumulations of power are stored away in a non-volatile memory. If measuring power is lost, when it returns, the meter will power up and still retain the latest recorded information. Reset of Watt-hours and Time is accomplished via the front panel momentary switches.

A dual line, 16 character per line, LCD provides a visual output to the operator. Two front-panel pushbuttons allow sequencing through the different displays of values. All measurements and calculations are updated at 1 second intervals, and if your meter includes the RS232 option, all the measurements and calculations are output at 9600 baud, once each second. RS232 isolation is a minimum of 1500 volts.

Operating temperature: $25 \pm 10$ degrees C. Bandpass: $100^{\text {th }}$ harmonic of $60 \mathrm{~Hz}(6 \mathrm{Khz})$.

Crest factor: Peak current (10 amps) divided by measured RMS current.

\begin{tabular}{lll} 
MEASUREMENT & RANGE & ACCURACY \\
\cline { 2 - 2 } RMS Voltage & 0.1 to 140.0 volts & $0.5 \%+1$ LSD \\
RMS Current & 0.001 to 3.000 amps & $0.5 \%+1$ LSD \\
Watts & 0.1 to 420.1 watts & $0.5 \%+1$ LSD \\
Peak Voltage & 0.1 to 200.0 volts & $1 \%+1$ LSD \\
Peak Current & 0.01 to 10.00 amps & $1 \%+1$ LSD \\
Peak Power & 1 to 2,000 watts & $1 \%+1$ LSD \\
Volt-Amps & 0.1 to $420.0 \mathrm{VA}$ & $1 \%+1$ LSD \\
Power Factor & 0.00 to 1.00 & $1.5 \%$ \\
VARS & 1 to 420 VARS & $1.5 \%$ (PF $=0.1$ to 0.9$)$ \\
Accumulate Power (Wh) & 0.01 to 999999.99 & $05 \%+1 \mathrm{LSD}$ \\
Hours & 0.01 to 655.36 & $0.01 \%+1 \mathrm{LSD}$
\end{tabular}


LBNL-45305 


\section{APPENDIX B. SET-TOP POWER MEASUREMENTS}

\section{Table B1. Analog Cable Box Power Measurements}

\begin{tabular}{|c|c|c|c|}
\hline Brand & Model & Standbv (W) & On $(W)$ \\
\hline General Instruments & CFT 2014/V558.1 & 12.6 & 13.8 \\
\hline General Instruments & CFT 2014/V558.2 & 11.1 & 11.9 \\
\hline General Instruments & DPV7-212P & 9.8 & 10.8 \\
\hline General Instruments & DQN5-3 & 6.0 & 6.8 \\
\hline General Instruments & DRZD-3A-AB & 11.8 & 12.9 \\
\hline General Instruments & Starcom VI (DPV5-212-R3). 1 & 12.6 & 14.1 \\
\hline General Instruments & Starcom VI (DPV5-212-R3).2 & 12.9 & 14.2 \\
\hline Jerrold & CFT 2024/S8 & 15.2 & 16.5 \\
\hline Jerrold & CFT2.24/V5S8 & 12.0 & 13.1 \\
\hline Jerrold & DP7113.1 & 8.1 & 9.2 \\
\hline Jerrold & DP7113.2 & 7.2 & 8.1 \\
\hline Jerrold & DPV5-210-R3 & 12.6 & 14.1 \\
\hline Jerrold & DPV7113P/R2B.1 & 9.3 & 10.9 \\
\hline Jerrold & DPV7113P/R2B.2 & 14.0 & 18.0 \\
\hline Jerrold & DPV7212 & 8.7 & 9.7 \\
\hline Jerrold & DPV7-212/V5.1 & 8.5 & 9.4 \\
\hline Jerrold & DPV7-212/V5.2 & 8.9 & 16.9 \\
\hline Jerrold & DPV7-212/V5.3 & 12.8 & 13.9 \\
\hline Jerrold & DPV7212/V5/B & 9.3 & 10.3 \\
\hline Jerrold & DPV7212/V5B & 9.8 & 10.6 \\
\hline Jerrold & DRZIN-3A-AB-E & 10.7 & 23.4 \\
\hline Radio Shack & $15-1288 \mathrm{~A}$ & 4.9 & 5.4 \\
\hline Scientific Atlanta & 8530338.1 & 2.4 & \\
\hline Scientific Atlanta & 8530338.2 & 9.0 & 9.7 \\
\hline Scientific Atlanta & 8511300 & 4.6 & 6.0 \\
\hline Scientific Atlanta & 8528300 & 6.3 & 7.1 \\
\hline Scientific Atlanta & 8529300.1 & 4.9 & 6.0 \\
\hline Scientific Atlanta & 8529300.2 & 4.8 & 5.8 \\
\hline Scientific Atlanta & 8529300.3 & 5.0 & 5.9 \\
\hline Scientific Atlanta & 8580338 & 8.3 & 9.3 \\
\hline Scientific Atlanta & 8590757 & 11.3 & 12.7 \\
\hline Scientific Atlanta & 8600 STNN.1 & 9.3 & 10.4 \\
\hline Scientific Atlanta & 8600STNN.2 & 9.7 & 10.7 \\
\hline Scientific Atlanta & 8600STNN.3 & & 9.8 \\
\hline Scientific Atlanta & 8600 SZNN & 10.6 & 11.6 \\
\hline Zenith & ST 1083 & 18.0 & 19.0 \\
\hline Zenith & ST 1085.1 & 18.0 & 19.0 \\
\hline Zenith & ST 1085.2 & 15.9 & 16.5 \\
\hline Zenith & ST 1601.1 & 9.7 & 9.9 \\
\hline Zenith & ST 1601.2 & 10.0 & 10.2 \\
\hline Zenith & ST 1601.3 & 16.9 & 17.1 \\
\hline Zenith & ST 1601.4 & 17.4 & \\
\hline Zenith & ST 1601.5 & 17.4 & 18.0 \\
\hline Zenith & ST 1622 & 12.3 & 13.0 \\
\hline
\end{tabular}




\section{LBNL-45305}

Table B2. Digital Cable Box Power Measurements

\begin{tabular}{|llcr|}
\hline Brand & Model & Standby (W) On $(W)$ \\
\hline General Instruments & DCT1000 & 19.7 & 20.5 \\
\hline General Instruments & DCT2000 & 23.3 & 23.8 \\
\hline General Instruments & Starfone SFT & 24.7 & 25.2 \\
\hline General Instruments & Starfone SFT2 & 24.0 & 24.4 \\
\hline
\end{tabular}

Table B3. Wireless Receiver Power Measurements

\begin{tabular}{|llll|}
\hline Brand & Model & Standby $(\mathbf{W})$ & On $(\mathbf{W})$ \\
\hline Hitachi & HDS110S & 13.8 & 13.9 \\
\hline Hughes & HIRD-B2.1A & 10.0 & 11.0 \\
\hline Hughes & HIRD-B2.1B & 9.9 & 11.2 \\
\hline Hughes & HIRD-B2.2A & 10.7 & 12.0 \\
\hline Hughes & HIRD-B2.2B & 9.5 & 11.0 \\
\hline Hughes & HIRD-B2.2c & 13.7 & 13.7 \\
\hline RCA & DRD303RA & 15.0 & 15.4 \\
\hline RCA & DRD502RB.1 & 9.0 & 9.4 \\
\hline RCA & DRD502RB.2 & 10.7 & 11.5 \\
\hline RCA & DRD503RBC.1 & 8.8 & 9.1 \\
\hline RCA & DRD503RBC.2 & 10.0 & 10.7 \\
\hline RCA & DRD515RB.1 & 10.1 & 10.9 \\
\hline RCA & DRD515RB.2 & 11.0 & 11.9 \\
\hline RCA & DS3130RA & 14.4 & 14.5 \\
\hline RCA & DS5450 RB & 15.9 & 16.2 \\
\hline RCA & & 16.0 & 16.5 \\
\hline Sony & SATA3.1 & 10.0 & 10.1 \\
\hline Sony & SATA3.2 & 13.8 & 14.0 \\
\hline Sony & SATA4.1 & 11.5 & 11.7 \\
\hline Sony & SATA4.2 & 11.4 & 11.4 \\
\hline Sony & SATB2 & 11.3 & 11.4 \\
\hline Sony & SATB3.1 & 9.1 & 9.3 \\
\hline Sony & SATB3.2 & 9.5 & 10.4 \\
\hline Sony & SATB3.2 & 10.1 & 10.5 \\
\hline Toshiba & TSS-111 & 14.4 & 14.7 \\
\hline Sony & SAS-AD2 & 16.3 & 16.4 \\
\hline EchoStar & ISD4000 & 16.8 & 17.2 \\
\hline RCA & DRD505RB & 17.2 & 17.7 \\
\hline ProScan & PS 84360A & 18.4 & 21.2 \\
\hline JVC & 4500 & 18.8 & 19.3 \\
\hline
\end{tabular}


Table B4. Game Console Power Measurements

\begin{tabular}{|lllcc|}
\hline & & & Standby & On \\
Brand & Model & Description & (W) & (W) \\
\hline Nintendo & NUS-001.5 & & 0.6 & 8.0 \\
\hline Nintendo & NUS-001.1 & 64-bit & 0.9 & 8.5 \\
\hline Nintendo & NUS-001.3 & Nintendo64 & 0.9 & 8.0 \\
\hline Nintendo & SNES-001 & Super Nintendo & 0.9 & 7.8 \\
\hline Nintendo & NES-001.2 & & 1.0 & 5.7 \\
\hline Sony & SCPH-1001 & Playstation & 1.0 & 7.9 \\
\hline Sony & SCPH7501 & Playstation & 1.0 & 5.7 \\
\hline Nintendo & NUS-001.2 & 64-bit & 1.3 & 8.1 \\
\hline Nintendo & NUS-001.4 & 64-bit & 1.3 & 9.0 \\
\hline Nintendo & NES-001.1 & 8-bit & 2.0 & 9.8 \\
\hline
\end{tabular}


LBNL-45305 


\section{APPENDIX C. TELEPHONY POWER MEASUREMENTS}

Table C1. Answering Machine Power Measurements

\begin{tabular}{|c|c|c|c|c|}
\hline Brand & Model & No-load & Standby & Play \\
\hline GE & $2-9873 \mathrm{~A}$ & & 1.8 & \\
\hline $\mathrm{GE}$ & $2-9805 \mathrm{~A}$ & & 1.8 & 3.5 \\
\hline AT\&T & 1325 & & 2.1 & 3.1 \\
\hline Panasonic & KX-T1427 & & 2.1 & 2.1 \\
\hline Panasonic & KX-T1470 & & 2.2 & \\
\hline Panasonic & KX-T5100 & & 2.2 & 4.2 \\
\hline Casio Phonemate & 3500 & & 2.3 & \\
\hline Casio Phonemate & TA-110 & 1.1 & 2.3 & 3.4 \\
\hline Lucent Technologies & 1325 & 1.6 & 2.4 & 3.5 \\
\hline Panasonic & KX-T1450 & & 2.4 & 6.0 \\
\hline AT\&T & 1300 & 1.3 & 2.5 & \\
\hline Casio Phonemate & 9800 & & 2.5 & \\
\hline Casio Phonemate & TA-120 & & 2.9 & 3 \\
\hline AT\&T & 1710 & & 3.0 & 3.1 \\
\hline Lucent Technologies & 1715 & 1.6 & 3.2 & 3.4 \\
\hline Casio Phonemate & TA-120 & & 3.3 & \\
\hline Casio Phonemate & TA-120 & 0.9 & 3.3 & 3.3 \\
\hline $\mathrm{GE}$ & $2-9865$ & & 3.3 & \\
\hline Casio Phonemate & TA-120 & & 3.4 & \\
\hline AT\&T & 1750 & & 3.7 & \\
\hline AT\&T & 1317 & & 3.7 & 4.4 \\
\hline AT\&T & 1418 & & 4.0 & \\
\hline AT\&T & 1750 & & 4.0 & \\
\hline AT\&T & 1343 & & 4.6 & \\
\hline AT\&T & 1337 & & 4.7 & \\
\hline Muratec & VF1000-1 & & 4.8 & \\
\hline AT\&T & 1323 & & 5.2 & \\
\hline
\end{tabular}


Table C2. Cordless Phone Power Measurements

\begin{tabular}{|c|c|c|c|c|c|c|}
\hline Brand & Model & No-load & Standby & Charge full ${ }^{\mathrm{a}}$ & Charge empty & Talk \\
\hline $\mathrm{GE}$ & 2-9910B & & 1.1 & 2.1 & 2.1 & 1.6 \\
\hline Lucent & 9200 & 0.6 & 1.9 & 2.0 & 2.0 & 2.4 \\
\hline AT\&T & 4340 & & 1.2 & 2.5 & 2.5 & 1.7 \\
\hline Toshiba & FT-8006A & 0.9 & 1.7 & 2.4 & 2.5 & 2.1 \\
\hline Radio Shack & Super OCT & & 1.7 & 2.7 & 2.7 & 1.5 \\
\hline AT\&T & 4605 & & 2.0 & 2.6 & 2.6 & 2.5 \\
\hline AT\&T & 5860 & & 2.0 & 2.6 & 2.6 & 2.5 \\
\hline AT\&T & 5200 & & 2.0 & 3.0 & 3.0 & 3.0 \\
\hline AT\&T & 5481 & & 2.2 & 3.0 & 3.0 & 2.7 \\
\hline Toshiba & FTH986 & 0.6 & 2.2 & 3.2 & 3.2 & 2.7 \\
\hline Bell South & HAC 3392 & & 2.3 & 3.3 & 3.3 & 2.1 \\
\hline Toshiba & FT-8006 & & 2.6 & 3.6 & 3.6 & 2.2 \\
\hline Sony & SPP-M920 & 0.6 & 2.2 & 3.8 & 3.8 & 2.7 \\
\hline Sony & SPPM932 & 1.0 & 2.7 & 3.7 & 3.7 & 3.1 \\
\hline Panasonic & KX-A11 & 2.1 & 2.9 & 3.8 & 3.8 & 2.7 \\
\hline Sony & SSP-SS960 & 1.2 & 3.2 & 4.2 & 4.2 & 3.1 \\
\hline Panasonic & KXTG200B & & 2.6 & 4.5 & 4.5 & 6.9 \\
\hline Panasonic & KXTG2400 & 0.8 & 2.0 & 4.7 & 4.7 & 7.0 \\
\hline AT\&T & 9120 & & 3.8 & 5.4 & 5.4 & 4.3 \\
\hline AT\&T & 5510 & & 4.1 & 5.5 & 5.5 & 4.6 \\
\hline
\end{tabular}

a. Estimated. 
Table C3. Combination Cordless-Phone/Answering-Machine Power Measurements

\begin{tabular}{|llllcccc|}
\hline & & & & & & & \\
Brand & Model & Battery & No-load & Standlby & Charge full & Charge empty & Talk \\
\hline Toshiba & FT-9005 & NiCd & 1.0 & 2.5 & 3.0 & 3.0 & 3.0 \\
\hline Toshiba & FT-9005 & NiCd & 1.0 & 2.5 & 3.0 & 3.0 & 3.0 \\
\hline Uniden & XCAI680 & NiCd & 0.9 & 2.1 & 3.2 & 3.2 & 2.6 \\
\hline Sony & SPP-AQ25 & NiCd & 1.1 & 2.8 & 3.3 & 3.3 & 3.3 \\
\hline Panasonic & KXTC1040 & NiCd & 0.8 & 2.9 & 3.3 & 3.3 & 3.2 \\
\hline Uniden & EXA7950 & NiCd & 0.6 & 2.4 & 3.5 & 3.5 & 3.3 \\
\hline Sony & SPP-AQ600 & NiCd & 1.1 & 2.5 & 3.6 & 3.6 & 3.0 \\
\hline Uniden & EXAI7980 & NiCd & 0.6 & 2.7 & 3.8 & 3.8 & 3.5 \\
\hline Sony & SPP-A400 & NiCd & 1.7 & 3.2 & 3.9 & 3.9 & 3.7 \\
\hline Uniden & EXA915 & $\mathrm{NiCd}$ & 0.9 & 3.0 & 4.0 & 4.0 & 4.2 \\
\hline Sony & SPPA941 & $\mathrm{NiCd}$ & 0.6 & 2.6 & 4.6 & 4.6 & 3.0 \\
\hline Panasonic & KXTC1500 & $\mathrm{NiCd}$ & 0.8 & 2.9 & 4.7 & 4.7 & 3.4 \\
\hline Panasonic & KXTC1740 & $\mathrm{NiCd}$ & 0.8 & 3.0 & 4.9 & 4.9 & 3.4 \\
\hline Panasonic & KXTG2570 & $\mathrm{NiMH}$ & 1.6 & 4.1 & 4.1 & 6.3 & 8.1 \\
\hline Sony & SPPA968 & $\mathrm{NiCd}$ & 1.2 & 3.1 & 5.0 & 5.0 & 3.9 \\
\hline Sony & SPPA973 & $\mathrm{NiCd}$ & 0.6 & 3.2 & 5.0 & 5.0 & 3.4 \\
\hline VTECH & VT1970ci & $\mathrm{NiCd}$ & 1.0 & 3.0 & 5.3 & 5.3 & 3.4 \\
\hline Panasonic & KXTC1870 & $\mathrm{NiCd}$ & 0.8 & 3.7 & 5.7 & 5.7 & 4.3 \\
\hline Sony & SPPA945 & $\mathrm{NiCd}$ & 0.6 & 3.6 & 6.6 & 6.6 & 4.1 \\
\hline AT\&T & 9450 & $\mathrm{NiCd}$ & 1.8 & 5.3 & 6.1 & 6.1 & 5.5 \\
\hline Uniden & EXR2480 & $\mathrm{NiCd}$ & 2.5 & 5.0 & 6.1 & 6.1 & 7.2 \\
\hline
\end{tabular}

a. Estimated. 


\section{LBNL-45305}

Table C4. Mobile Phone Charger Power Measurements

\begin{tabular}{|llcc|}
\hline & & & \\
\hline Brand & Model & No-load & Standloy \\
\hline Nokia & ACP-7U & 0.4 & 0.4 \\
\hline LG & & 0.2 & 0.2 \\
\hline Audiovox & & 0.3 & 0.3 \\
\hline Motorola & StarTac & 0.2 & 0.2 \\
\hline Qualcomm & TAACA0101 & 1.4 & 1.4 \\
\hline LG & & 0.8 & 0.8 \\
\hline Motorola & IntelliChargeXT & & 2.9 \\
\hline
\end{tabular}

